\title{
The Contribution of Small Phytoplankton Communities to the Total Dissolved Inorganic Nitrogen Assimilation Rates in the East/Japan Sea: An Experimental Evaluation
}

\author{
Panthalil S. Bhavya ${ }^{1,2}$, Jae Joong Kang ${ }^{1}$, Hyo Keun Jang ${ }^{1}$, HuiTae Joo ${ }^{3}$, Jae Hyung Lee ${ }^{1,4}$, \\ Jang Han Lee ${ }^{5}$, Jung Woo Park ${ }^{6}$, Kwanwoo Kim ${ }^{1}$, Hyung Chul Kim ${ }^{7}$ and Sang Heon Lee ${ }^{1, *} \mathbb{D}$ \\ 1 Department of Oceanography, Pusan National University, Geumjeong-gu, Busan 609-735, Korea; \\ bhavya.panthalil@tum.de (P.S.B.); jaejung@pusan.ac.kr (J.J.K.); janghk@pusan.ac.kr (H.K.J.); \\ tlyljh78@pusan.ac.kr (J.H.L.); goanwoo7@pusan.ac.kr (K.K.) \\ 2 Chair of Aquatic Systems Biology, School of Life Science Systems, Technical University of Munich, \\ 853554 Freising, Germany \\ 3 Oceanic Climate and Ecology Research Division, National Institute of Fisheries Science, Busan 46083, Korea; \\ huitae@pusan.ac.kr \\ 4 South Sea Fisheries Research Institute, National Institute of Fisheries Science, Yeosu-si 59780, Korea \\ 5 Department de Biologie and Quebec-Ocean, Université, Laval, QC G1V 0A6, Canada; \\ janghan.lee.1@ulaval.ca \\ 6 Graduate School of Fisheries Sciences, Hokkaido University, Hakodate, Hokkaido 041-8611, Japan; \\ park@salmon.fish.hokudai.ac.jp \\ 7 Marine Environmental Impact Assessment Center, National Institute of Fisheries Science, Busan 46083, \\ Korea; hckim072@korea.kr \\ * Correspondence: sanglee@pusan.ac.kr
}

Received: 17 September 2020; Accepted: 23 October 2020; Published: 29 October 2020

\begin{abstract}
As a part of Korean-Russian joint expeditions in the East/Japan Sea during 2012 and 2015, a set of total and small $(<2 \mu \mathrm{m})$ phytoplankton $\mathrm{NO}_{3}{ }^{-}$and $\mathrm{NH}_{4}{ }^{+}$uptake rate estimations were carried out. The study aimed to assess the spatio-temporal variations in dissolved inorganic nitrogen (DIN) assimilation by the total and small phytoplankton. The results show that the total $\mathrm{NO}_{3}{ }^{-}$uptake rates during 2012 varied between 0.001 and $0.150 \mu \mathrm{mol} \mathrm{NL}{ }^{-1} \mathrm{~h}^{-1}$ (mean $\pm \mathrm{SD}=0.034 \pm 0.033$ ) and that the total $\mathrm{NH}_{4}{ }^{+}$uptake rates ranged between 0.002 and $0.707 \mu \mathrm{mol} \mathrm{NL}{ }^{-1} \mathrm{~h}^{-1}$ (mean $\left.\pm \mathrm{SD}=0.200 \pm 0.158\right)$. The total uptake rates during 2015 were ranged

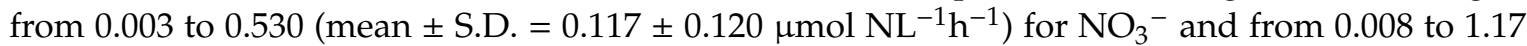
(mean \pm S.D. $=0.199 \pm 0.266 \mathrm{NL}^{-1} \mathrm{~h}^{-1}$ ) for $\mathrm{NH}_{4}{ }^{+}$. The small phytoplankton $\mathrm{NO}_{3}{ }^{-}$and $\mathrm{NH}_{4}{ }^{+}$uptake rates during 2015 ranged between 0.001 and 0.164 (mean \pm S.D. $=0.033 \pm 0.036) \mu \mathrm{mol} \mathrm{NL}^{-1} \mathrm{~h}^{-1}$ and 0.010-0.304 (mean \pm S.D. $=0.101 \pm 0.073) \mu \mathrm{mol} \mathrm{NL}^{-1} \mathrm{~h}^{-1}$, respectively. Small phytoplankton's contribution to the total depth-integrated $\mathrm{NO}_{3}{ }^{-}$and $\mathrm{NH}_{4}{ }^{+}$uptake rates ranged from 10.24 to $59.36 \%$ and from 30.21 to $68.55 \%$, respectively. The significant negative relationship observed between the depth-integrated total $\mathrm{NO}_{3}{ }^{-}$and $\mathrm{NH}_{4}{ }^{+}$uptake rates and small phytoplankton contributions indicates a possible decline in the DIN assimilation rates under small phytoplankton dominance. The results from the present study highlight the possibility of a reduction in the total DIN assimilation process in the East/Japan Sea when small phytoplankton dominate under strong thermal stratification due to sea surface warming. The present study's findings agree with the model projections, which suggested a decline in primary production in the global warming scenario.
\end{abstract}

Keywords: East/Japan Sea; small phytoplankton; nitrogen uptake; global warming 


\section{Introduction}

The East/Japan Sea is a small, semi-enclosed marginal sea of the Pacific Ocean with boundaries shared by Korea, Japan, and Russia; however, there is no direct water mass exchange with Pacific Ocean waters [1-3]. The biological and physico-chemical processes in the East/Japan Sea are mainly controlled by the inward and outward flows of straits from neighboring seas. The northern part of the East/Japan Sea remains cold throughout the year due to the cold Liman current, whereas the southern part is warm due to the Tsushima warm current [1-3]. Subsequently, the East/Japan Sea is highly dynamic with frequent eddies, subpolar fronts, and coastal upwellings [4-6]. Thus, there are many hotspots in the East/Japan Sea that are critical areas of high primary production and subsequent high fish abundance [5-10].

Previous studies suggest that the East/Japan Sea possesses higher primary production (246.8 $\mathrm{g} \mathrm{C} \mathrm{m}^{-2} \mathrm{y}^{-1}$ ) rate than the open waters in various global oceans (55 $\mathrm{g} \mathrm{C} \mathrm{m}^{-2} \mathrm{y}^{-1}$ to $102 \mathrm{~g} \mathrm{C} \mathrm{m}^{-2} \mathrm{y}^{-1}$ ) [10]. The higher primary production is likely because the East/Japan Sea receives or possesses sufficient nutrients in the euphotic water column through various physico-chemical processes. A significant set of spatio-temporal assessments of nutrient concentrations and physical processes has already been conducted in the East/Japan Sea. The influence of physicochemical properties on primary production in the East/Japan Sea has also been widely investigated in the recent past [5-10]. However, the assimilation of inorganic nutrients such as $\mathrm{NO}_{3}{ }^{-}$and $\mathrm{NH}_{4}{ }^{+}$and the factors influencing nitrogen cycling in the East/Japan Sea is understudied. The uptake efficiency of inorganic nutrients by phytoplankton is one of the significant parts of sustainable primary production. Like primary production, inorganic nutrient uptake is also highly dependent on various factors, such as water temperature, salinity, nutrient availability, and chlorophyll $a(\mathrm{Chl}-a)$ concentration [11]. Apart from these parameters, DIN uptake is highly dependent on the types of phytoplankton species and their abundances [12].

Recent observational and modeling studies from various global oceans suggest that warming oceanic environments can alter phytoplankton size distribution [11-17]. These studies indicate that there will be an increase in small phytoplankton abundance and a considerable decrease in large phytoplankton population abundance. In addition to the rise in small phytoplankton abundance, small phytoplankton contributions toward total C and DIN uptakes were also reported to be enhanced [11-17].

The East/Japan Sea exhibits highly variable physico-chemical conditions introduced due to seasonal and climatological factors [10,17-21]. A significant number of investigations in the East/Japan Sea observed a remarkable change in small phytoplankton communities' biological characteristics at both local and broad scales due to environmental changes [10,22-24]. However, only a few studies have reported DIN uptake by small phytoplankton, particularly small phytoplankton's contribution in the East/Japan Sea [24]. It is reported that the sea surface temperature (SST) in the East/Japan Sea has drastically increased over several decades $[18,19]$. The increase in SST has resulted in alterations in the seasonal peak in abundance and community structure of phytoplankton and, subsequently, higher trophic levels in various global oceans (11-16). To understand the seasonal and spatial distributions of primary production, a set of carbon uptake measurements of total and small phytoplankton were conducted during 2012 and 2015 by our parallel study [24]. They reported that the phytoplankton contributions toward the total primary production were significantly lower than those toward the total biomass. Our study presents the DIN uptake rates by total and small phytoplankton during 2012 and 2015. The main objective was to estimate small and large phytoplankton contributions to the total DIN uptake rates. The present study also addresses the temporal and spatial distributions of the DIN uptake rates by phytoplankton in the East/Japan Sea, mainly in the Russian territory, an understudied region concerning DIN assimilation by small and large phytoplankton. 


\section{Materials and Methods}

\subsection{Study Area and Sampling}

The $\mathrm{NO}_{3}{ }^{-}$and $\mathrm{NH}_{4}{ }^{+}$uptake rate measurements were conducted in the East/Japan Sea at 10 (Stations M1, M4, M5, M11, M14, M17, 134-4, 134-6, 134-9, and 136-5) and 9 (Stations M6, M10, M12, M15, 134-2A, 134-5, 143, 149A, and 153A) stations on 13-29 October 2012 and 11 April-2 May 2015, respectively (Figure 1). The Korean-Russian joint cruises onboard R/V Akademik Oparin and R/V Akademik M. A Lavertiev assisted in the 2012 and 2015 expeditions, respectively. The water samples (10 L) for the various environmental parameters were collected from six light levels (100\%, 50\%, 30\%, $12 \%, 5 \%$, and $1 \%$ ) using Niskin bottles attached to the $\mathrm{CTD} /$ rosette sampler. Nutrients $\left(\mathrm{NO}_{3}{ }^{-}\right.$and $\mathrm{NH}_{4}{ }^{+}$) and Chl- $a$ samples were collected from 6 light depths (100\%, 50\%, 30\%, 12\%, 5\%, and 1\% photosynthetically active radiation (PAR)). The underwater PAR sensor was not available during the present study; hence, the light depths were determined based on the euphotic depth derived from the Secchi disk depth. The formula (euphotic depth $=2.81 \times$ Secchi depth) to determine euphotic depth was obtained from [25], where euphotic depth is the depth at which the light percentage decreases to a level of $1 \%$ of its surface level. Secchi disc depths were measured at all the productivity-measured stations during the cruise periods using a $30 \mathrm{~cm}$ black and white Secchi disk. Before sampling waters, the Secchi disc was lowered by attaching to a rope marked with $0.5 \mathrm{~m}$ intervals to disappear from view.

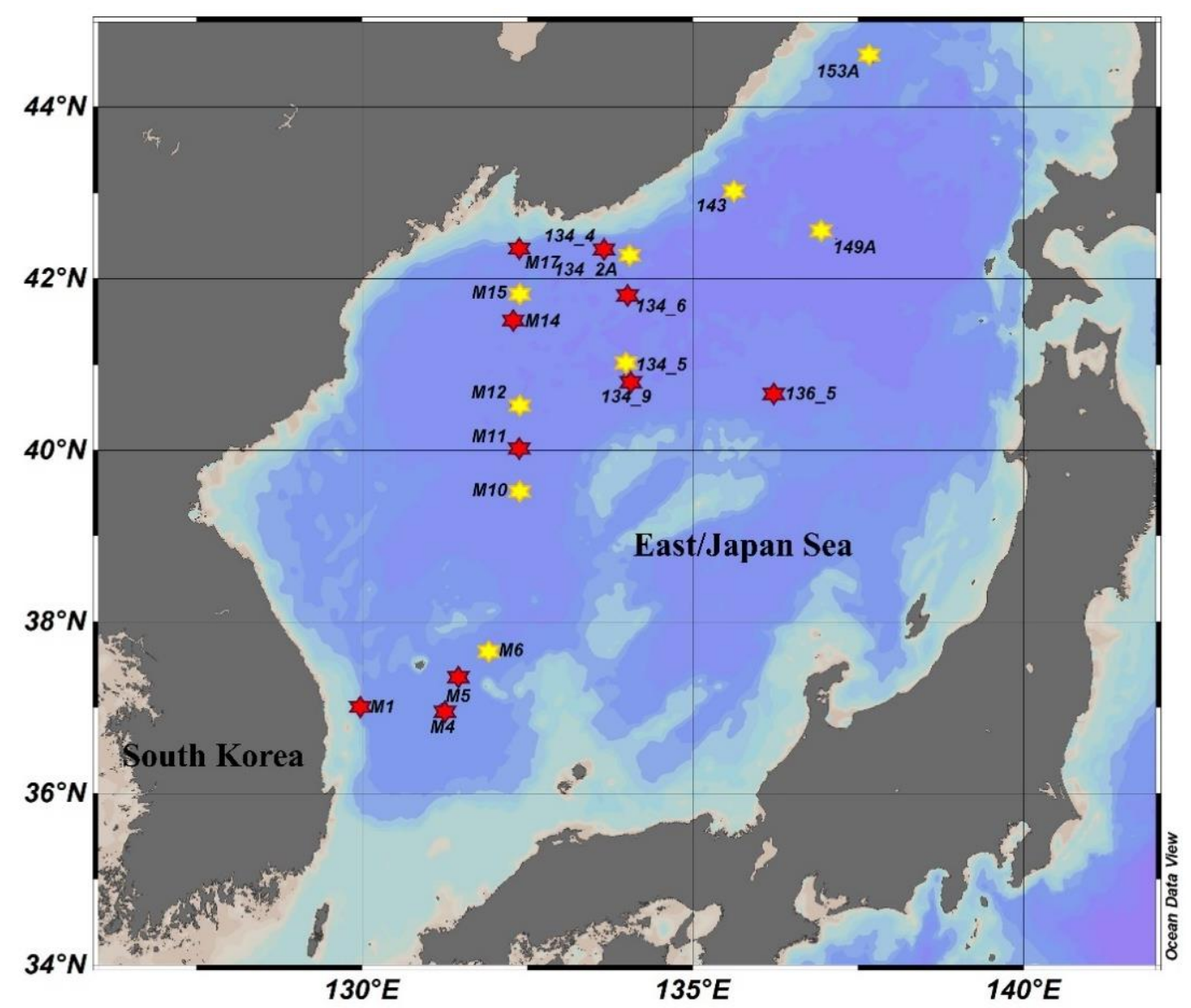

Figure 1. Sampling locations in the East/Japan Sea. The red stars indicate the sampling locations during 2012, and the yellow stars indicate the stations during the 2015 sampling.

Samples $(0.5 \mathrm{~L})$ for total Chl- $a$ were prepared by filtering them through $25 \mathrm{~mm}$ diameter Whatman GF/F (nominal pore size $=0.7 \mu \mathrm{m}$ ) filters using a low vacuum pressure at less than $5 \mathrm{inHg}$. For small phytoplankton, the Chl- $a$ concentration samples were prepared by subsequent filtration of water samples $(1.0 \mathrm{~L})$ through 20 - and $2-\mu \mathrm{m}$ Nucleopore filters $(47 \mathrm{~mm})$ and $0.7-\mu \mathrm{m}$ Whatman 
GF/F filters $(47 \mathrm{~mm})$ [26,27]. Furthermore, the samples were wrapped in aluminum foil and kept frozen until analysis. The measurement of Chl- $a$ concentrations was conducted at Pusan National University (home laboratory), Busan, South Korea, within one month after sampling. Before the measurements, the samples were extracted in $90 \%$ acetone, kept at $5{ }^{\circ} \mathrm{C}$ for $24 \mathrm{~h}$. After the extraction, the samples were centrifugated at $3500 \mathrm{rpm}$. The absorbance of the clear supernatant was measured using a Turner Designs model 10-AU fluorometer calibrated with commercially purified Chl-a preparations. The method for chlorophyll-a calculation followed that of [28].

\subsection{Nutrient Measurements}

The water samples for nutrient concentrations were collected from the light depths corresponding to the DIN uptake sampling depths using Niskin samplers attached to the CTD device. After collection, the water samples $(0.1 \mathrm{~L})$ were filtered through Whatman $\mathrm{GF} / \mathrm{F}$ filters at a low vacuum pressure less than $5 \mathrm{inHg}$. The filtrate was stored in airtight bottles at a temperature of $-80{ }^{\circ} \mathrm{C}$ until the $\mathrm{NO}_{3}{ }^{-}$ and $\mathrm{NH}_{4}{ }^{+}$concentrations analysis. The frozen samples were thawed before analysis and analyzed at the National Institute of Fisheries Science, Korea, using an Auto analyzer (Quattro, Bran+Luebbe, Norderstedt, Germany) within two months after sampling.

\subsection{DIN Uptake Rate Measurements}

The DIN uptake estimations were conducted using the ${ }^{13} \mathrm{C}-{ }^{15} \mathrm{~N}$ dual isotope tracer technique. Furthermore, the water samples from each light depth were transferred to polycarbonate incubation bottles (approximately $1.1 \mathrm{~L}$ ) through a $200 \mu \mathrm{m}$ net to remove zooplankton to avoid grazing during incubation. The sample bottles were covered with light filtering screens (LEE Filters; [24,29]) corresponding to each light depth. Furthermore, the samples for $\mathrm{NO}_{3}{ }^{-}$and $\mathrm{NH}_{4}{ }^{+}$uptake were supplied with $98^{+} \%$ enriched $\mathrm{NO}_{3}{ }^{-}\left(\mathrm{K}^{15} \mathrm{NO}_{3}\right)$ and $\mathrm{NH}_{4}{ }^{+}\left({ }^{15} \mathrm{NH}_{4} \mathrm{Cl}\right)$ substrates, respectively, in addition to $\mathrm{NaH}^{13} \mathrm{CO}_{3}$ [30-33], and were subjected to deck incubation for $4 \mathrm{hrs}$ in large polycarbonate incubators with running surface seawater under natural light conditions. However, incubation times were longer, as long as $6 \mathrm{hrs}$, under cloudy weather conditions than under natural light conditions.

For total phytoplankton DIN uptake, $300 \mathrm{~mL}$ of each post-incubation sample was filtered onto pre-combusted $\left(450{ }^{\circ} \mathrm{C}\right) \mathrm{GF} / \mathrm{F}$ filters $(25 \mathrm{~mm}$ diameter and $0.7 \mu \mathrm{m}$ pore size). For the small phytoplankton DIN uptake rates, the incubated samples underwent two sets of filtrations. Initially, $600 \mathrm{~mL}$ of each incubated sample was passed through $2 \mu \mathrm{m}$ pore size Nucleopore filters. The filtrate was further filtered through $0.7 \mu \mathrm{m} \mathrm{GF} / \mathrm{F}$ filters $(25 \mathrm{~mm}$ diameter) to collect small phytoplankton. Both sample filters were immediately stored at $-80^{\circ} \mathrm{C}$ for preservation until mass spectrometric analysis at the stable isotope laboratory of the University of Alaska, Fairbanks, AL, USA. The experiments for small phytoplankton uptake rates were also conducted in parallel during 2012 and 2015; however, most of the data were not presentable for the 2012 sampling due to measurement-related issues. Hence, the small phytoplankton uptake rate data during 2015 are only discussed here. The calculations of DIN uptake rates were performed based on the equations given in Dugdale and Wilkerson [30]:

$$
\text { Uptake rate }\left(\mu \mathrm{mol} \mathrm{N} 1^{-1} \mathrm{~h}^{-1}\right)=\mathrm{P} * \Delta \mathrm{I}_{\mathrm{p}} /\left(\mathrm{T} *\left(\mathrm{I}_{0} \mathrm{~S}_{\mathrm{a}}+\mathrm{I}_{\mathrm{r}} \mathrm{S}_{\mathrm{t}}\right) /\left(\mathrm{S}_{\mathrm{a}}+\mathrm{S}_{\mathrm{t}}\right)-\mathrm{I}_{0}\right)
$$

where $P$ represents the amount of particulate organic nitrogen in the post-incubation sample, and $\Delta I_{p}$ represents the increase in ${ }^{15} \mathrm{~N}$ atom\% in the particulate $\mathrm{N}$ during incubation. $\mathrm{S}_{\mathrm{a}}$ and $\mathrm{S}_{\mathrm{t}}$ are ambient nutrients and added tracer concentrations, respectively. $\mathrm{I}_{\mathrm{r}}$ and $\mathrm{I}_{0}$ are ${ }^{15} \mathrm{~N}$ atom $\%$ of added tracer and natural ${ }^{15} \mathrm{~N}$ atom $\%$, and $\mathrm{T}$ is the incubation time in hours. This equation assumes no formation of nutrients during incubation, and, therefore, values obtained here are representatives of potential DIN uptake rates.

The measurements were performed two biological replicates, whereas technical replicates were performed only for the standards. Since the particulate organic content in the samples was very low, we could not keep the samples for technical replicates. The isotopic compositions were calculated with 
reference to the international standards Pee Dee Belemnite (PDB) and air standards for carbon and nitrogen measurements, respectively. However, there were IAEA lab standards measured at regular intervals during the sample measurements. Uncertainties in the $\delta^{13} \mathrm{C}$ and $\delta^{15} \mathrm{~N}$ isotope measurements are 0.1 and $0.3 \%$, respectively. The statistical analysis for the present study used linear regression analysis and Student's $t$-test to evaluate the significance of relationships between various parameters.

\section{Results and Discussion}

The results from the present study explain spatial and temporal variations in concentrations of $\mathrm{NO}_{3}{ }^{-}, \mathrm{NH}_{4}{ }^{+}, \mathrm{Chl}-a$, and DIN uptake rates in the East/Japan Sea during fall in 2012 and early spring in 2015. The temperature distribution in the euphotic zone during 2012 varied between 16.1 and $24.9^{\circ} \mathrm{C}$. The SST during 2012 varied between 16.8 and $24.9^{\circ} \mathrm{C}$, which indicates that vertical mixing existed throughout the euphotic zone (Table 1). During the 2015 sampling, the water column temperatures were lower than those of 2012, and SST varied between 2.58 and $13.6{ }^{\circ} \mathrm{C}$; however, the temperature-depth profile indicated significant vertical mixing (Table 1).

Table 1. Temperature data from the sampling stations during the fall in 2012 and early spring in 2015 sampling in the East/Japan Sea.

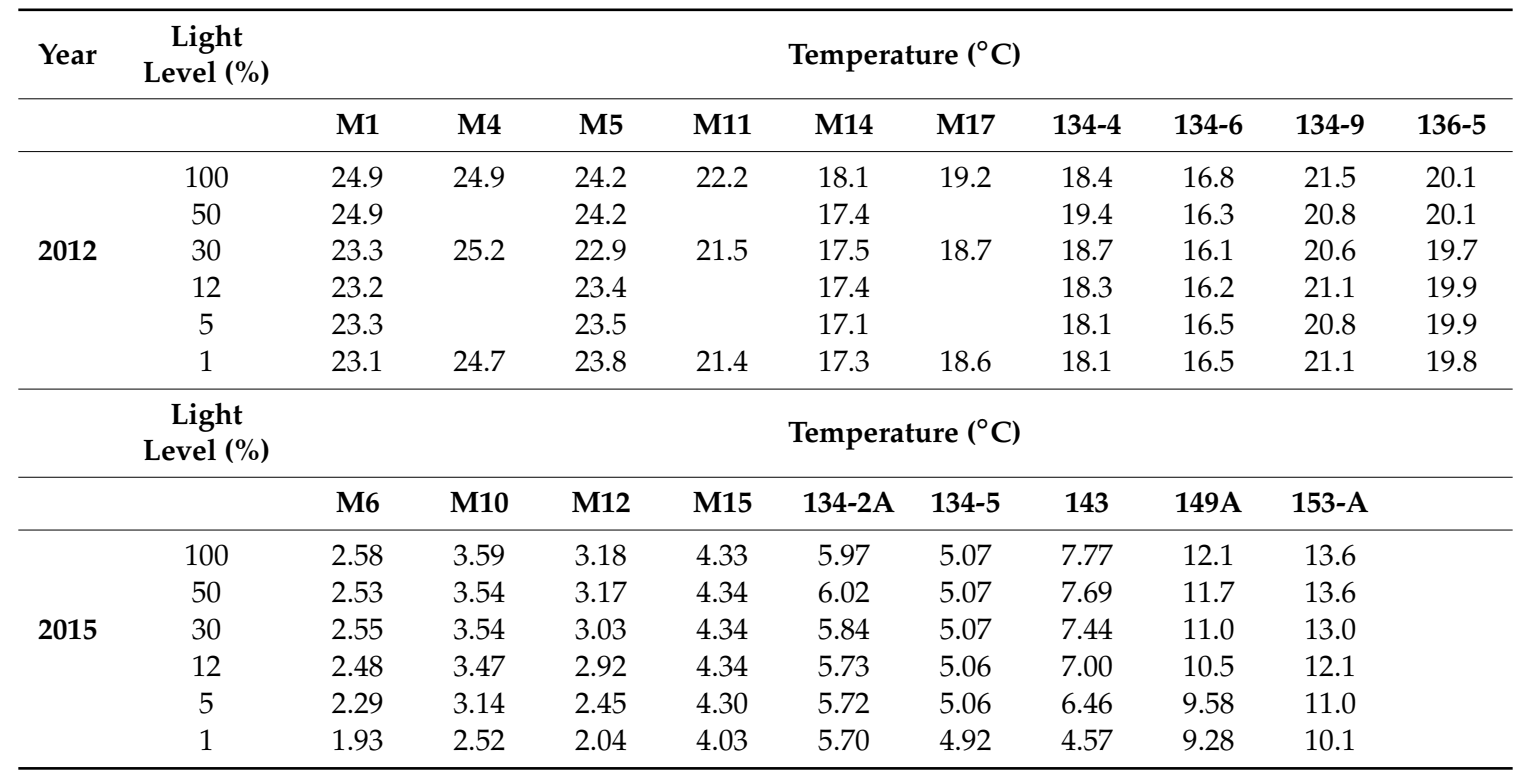

The distribution of Chl- $a$ concentrations in the various plankton size ranges obtained during the present study was previously reported in our parallel research work [24]. Lee et al. [24] noted that the total Chl- $a$ concentrations ranged from 0.07 to $1.36 \mathrm{mg} \mathrm{m}^{-3}$ (mean $\pm \mathrm{SD}=0.49 \pm 0.29 \mathrm{mg} \mathrm{m}^{-3}$ ) during the 2012 sampling effort. The Chl- $a$ concentrations observed during the 2015 sampling effort $\left(0.19-5.65 \mathrm{mg} \mathrm{m}^{-3}\right.$; mean $\left.\pm \mathrm{SD}=2.28 \pm 1.47 \mathrm{mg} \mathrm{m}^{-3}\right)$ were significantly higher than those of 2012 (data not shown in this paper) [24]. The Chl- $a$ values did not show any remarkable spatial distribution during the 2012 sampling. In contrast, stations M15, 134-2A, 143, 149A, and 153-A showed higher Chl- $a$ than at rest stations during the 2015 sampling. During both the sampling periods, the Chl- $a$ concentrations were distributed evenly throughout the euphotic zone, and no signs of subsurface stratifications or subsurface chlorophyll maximum layers were observed. Nevertheless, there was considerable variability in the Chl-a concentrations during the 2015 sampling. Lee et al. [24] also reported, based on the Chl-a size distribution pattern, that small phytoplankton was more dominant in the northern region than in the southern part during the cruise in 2012 (mean $\pm \mathrm{SD}=49.7 \% \pm 16.5 \%$ ). However, during the 2015 sampling, large phytoplankton was observed to be prominent (47.7-72.5\%) at the Russian coast (M15, 134-2A, 143, and 149A). Lee et al. [24] also found that the small phytoplankton contributions to primary productivity based on the Chl- $a$ concentrations were similar to the previous 
results observed in the East/Japan Sea during summer [34]. There were no significant correlations between primary productivity and Chl- $a$ concentration observed by Lee et al. [24]. The results from the present study also could not find any significant relationship between the DIN assimilation rates and the Chl- $a$ concentrations during either sampling period in the East/Japan Sea (figure not shown).

Nutrient availability is one of the critical factors that can influence potential DIN uptake [35]. Since no large rivers enter the East/Japan Sea, the significant sources of nutrients are upwelling and ocean currents [4-6]. The $\mathrm{NO}_{3}{ }^{-}$concentrations during 2012 varied between 0.004 and $11.65 \mu \mathrm{M}$, and, during 2015, they varied between 0.03 and $11.27 \mu \mathrm{M}$. Except for station 134-5, all other stations were seen with an elevated $\mathrm{NO}_{3}{ }^{-}$concentration at the bottom of the euphotic zone. Interestingly, station 134-5 showed the highest nutrient concentration among the rest of the stations. The elevated and uniformly distributed $\mathrm{NO}_{3}{ }^{-}$concentration at this station indicates the presence of upwelling (Figure 2b). Stations 143 and 153A also possessed uniform $\mathrm{NO}_{3}{ }^{-}$concentration till $5 \%$ light levels from the surface, which indicate the well-mixed water column. Another possible reason for low surface and elevated deep water column nutrient concentrations is the higher consumption of nutrients at surface layers than the dark bottom waters.

In general, the distribution pattern of the $\mathrm{NO}_{3}{ }^{-}$concentrations during both sampling periods showed a wide range compared to that of the $\mathrm{NH}_{4}{ }^{+}$concentrations. During the 2012 sampling, station M11 showed a significantly high $\mathrm{NH}_{4}{ }^{+}$concentration at the surface; however, the maximum $\mathrm{NH}_{4}{ }^{+}$concentration was observed at station $134-4$ at the $5 \%$ and $1 \%$ light levels (Figure 2a). $\mathrm{NH}_{4}{ }^{+}$ concentrations in the euphotic zone showed relatively high values during 2012, of which the stations, station 134-5, showed the highest value throughout the euphotic zone (Figure 2b).

Overall, the $\mathrm{NH}_{4}{ }^{+}$concentrations during the 2012 sampling were higher than those during the 2015 sampling. There was no considerable difference in the $\mathrm{NH}_{4}{ }^{+}$concentrations throughout the euphotic zone; however, stations (M1, M11, M14, and M17) exhibited considerably higher values near the bottom of the euphotic zone than the surface values during the 2012 sampling. The elevated $\mathrm{NH}_{4}{ }^{+}$ concentrations at the bottom of the euphotic zone were also seen during the 2015 sampling (stations; M6, M10, M12, 143, 149A, and 153A) (Figure 2b). 

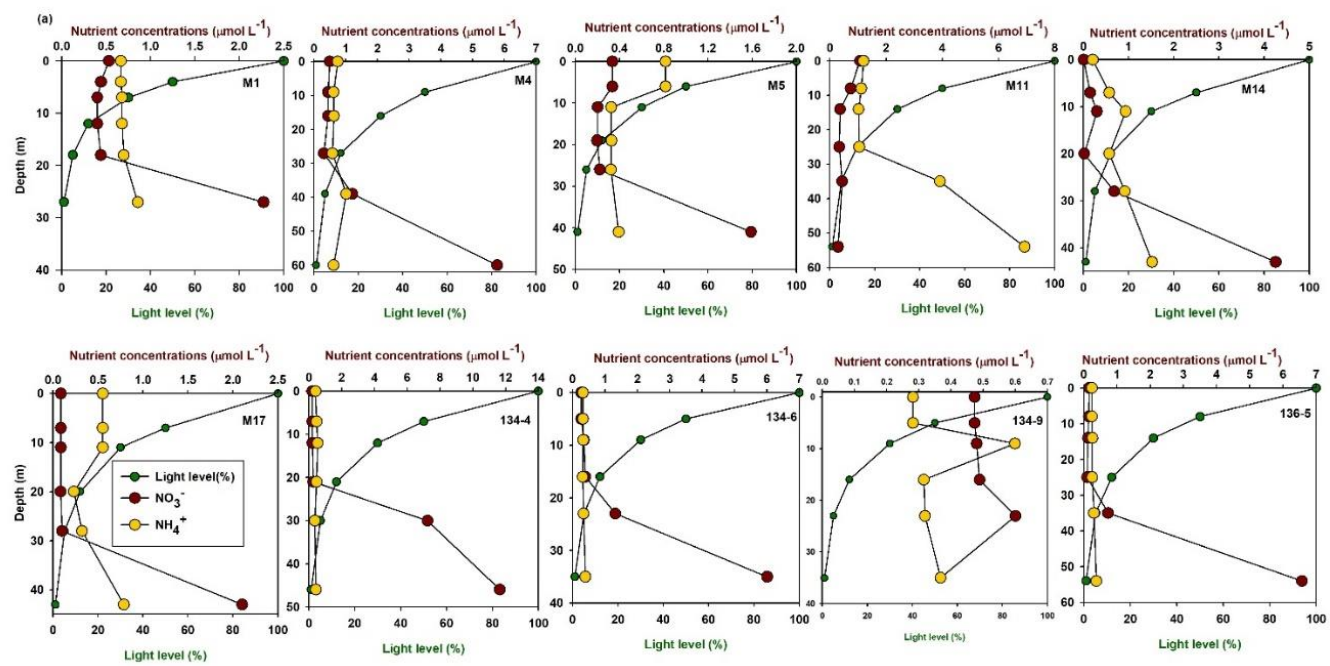

(b) Nutrient concentrations $\left(\mu \mathrm{mol} \mathrm{L}{ }^{-1}\right)$

Nutrient concentrations $\left(\mu \mathrm{mol} \mathrm{L}^{-1}\right) \quad$ Nutrient concentrations $\left(\mu \mathrm{mol} \mathrm{L}^{-1}\right)$
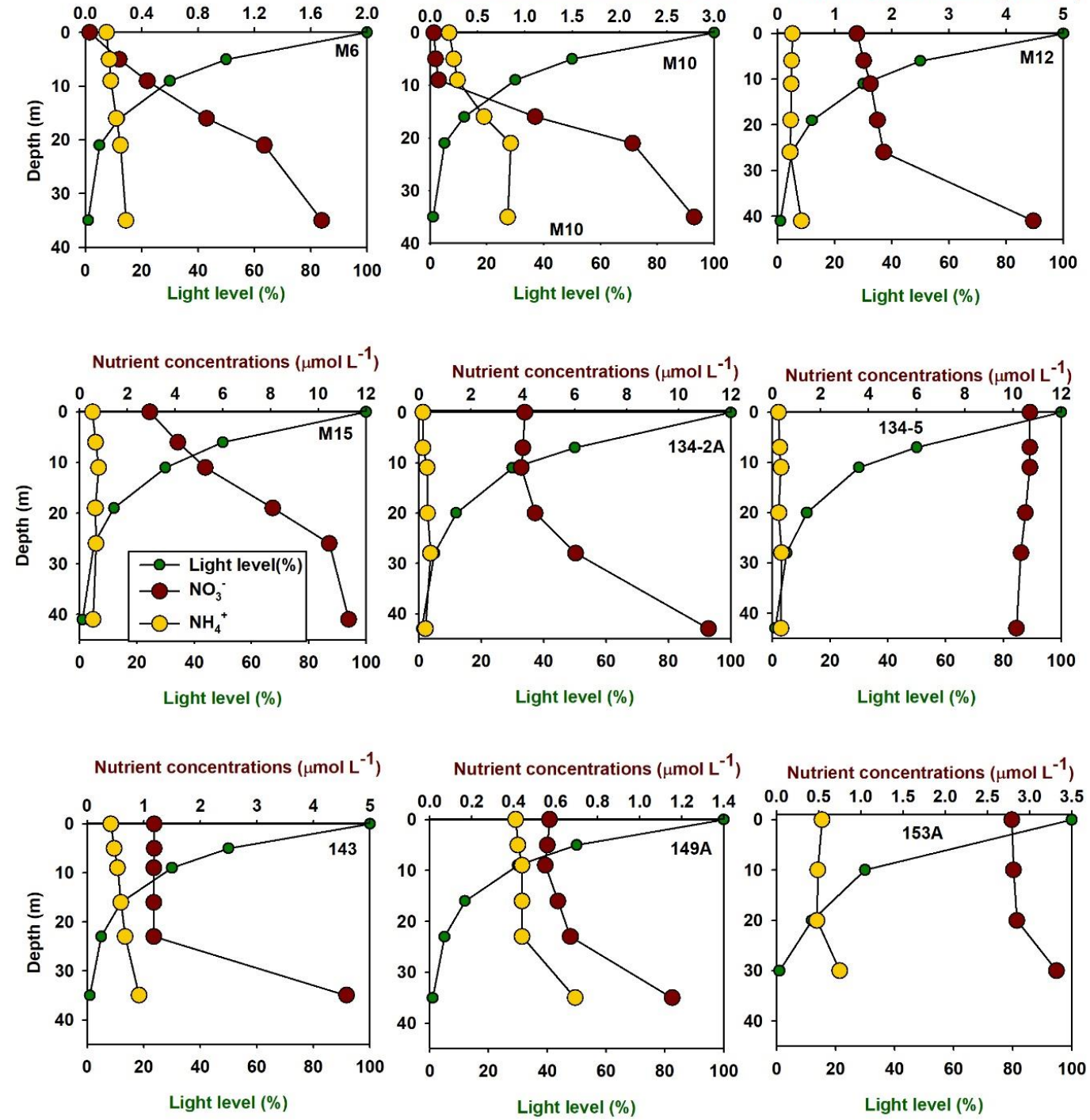

Figure 2. The depth profiles of the nutrient concentrations in the East/Japan Sea and the corresponding light levels for each station during 2012 (a) and 2015 (b). The station numbers are given on corresponding plots. 


\subsection{Spatiotemporal Distribution of DIN Uptake Rates}

Figures 3 and 4 show the depth profiles of the total $\mathrm{NO}_{3}{ }^{-}$and $\mathrm{NH}_{4}{ }^{+}$uptake rates estimated from the East/Japan Sea during 2012 and 2015. The results show that the total $\mathrm{NO}_{3}{ }^{-}$uptake rates during 2012 varied between 0.001 and $0.150 \mu \mathrm{mol} \mathrm{Nl}{ }^{-1} \mathrm{~h}^{-1}$ (mean \pm S.D. $=0.034 \pm 0.033$ ) and that the total $\mathrm{NH}_{4}{ }^{+}$ uptake rates ranged between 0.002 and $0.707 \mu \mathrm{mol} \mathrm{Nl}^{-1} \mathrm{~h}^{-1}$ (mean \pm S.D. $=0.200 \pm 0.158$ ) (Figure 3a).
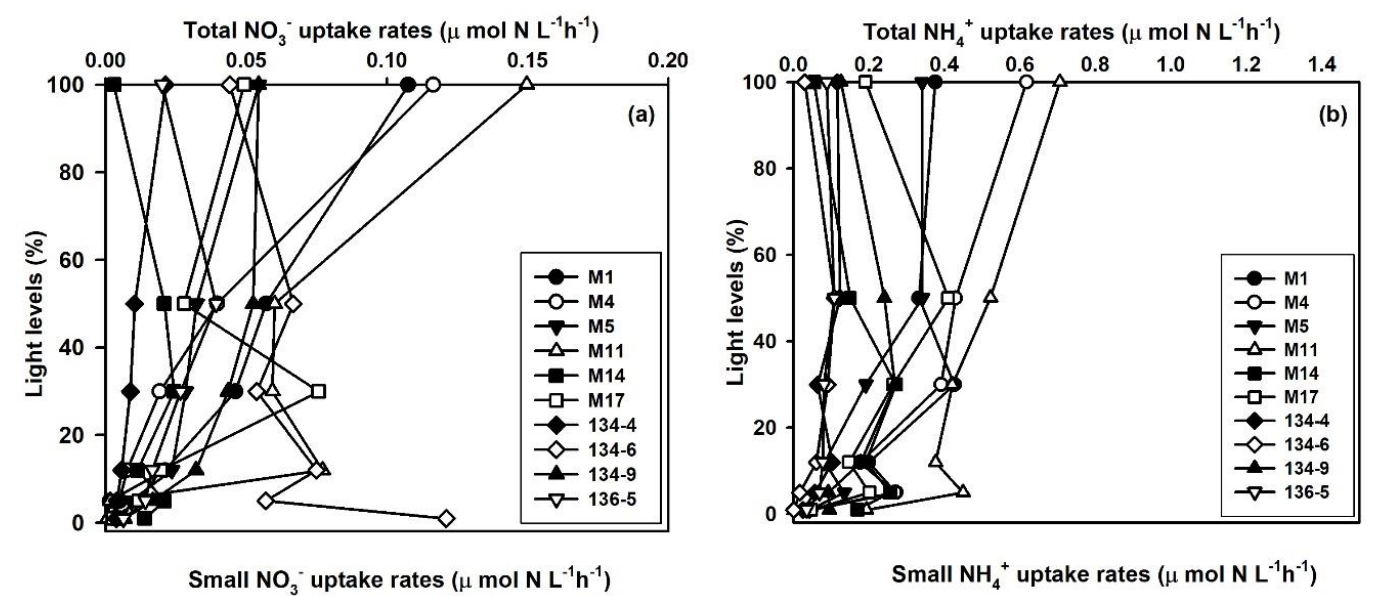

Figure 3. Depth profiles of total (a) $\mathrm{NO}_{3}{ }^{-}$and (b) $\mathrm{NH}_{4}{ }^{+}$uptake rates in the East/Japan Sea during 2012.
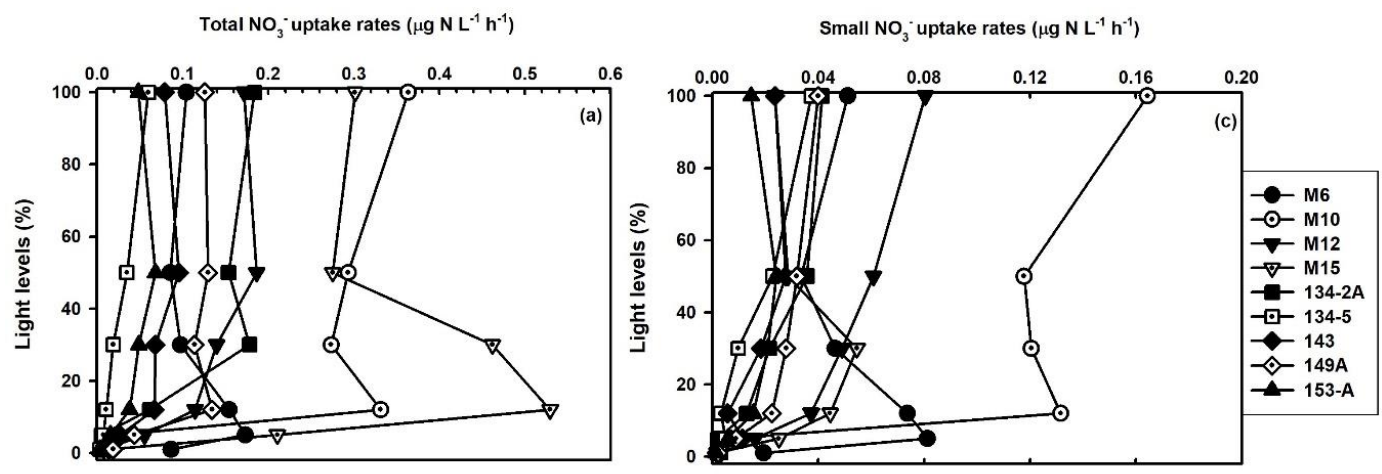

Total $\mathrm{NH}_{4}{ }^{+}$uptake rates $\left(\mu \mathrm{g} \mathrm{N} \mathrm{L}^{-1} \mathrm{~h}^{-1}\right)$
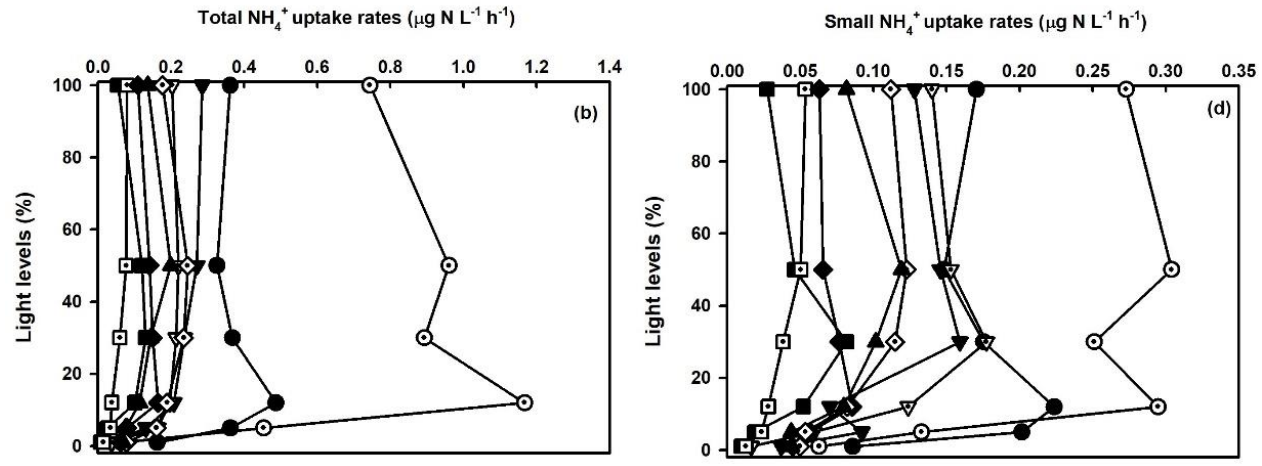

Figure 4. Depth profiles of total and small $\mathrm{NO}_{3}{ }^{-}$and $\mathrm{NH}_{4}{ }^{+}$uptake rates in the East/Japan Sea during 2015. (a,b) denote the total phytoplankton $\mathrm{NO}_{3}{ }^{-}$and $\mathrm{NH}_{4}{ }^{+}$uptake rates, respectively, and the (c) and (d) denote the small phytoplankton $\mathrm{NO}_{3}{ }^{-}$and $\mathrm{NH}_{4}{ }^{+}$uptake rates, respectively.

Compared to the other stations, stations M1, M4, and M11 showed relatively higher surface $\mathrm{NO}_{3}{ }^{-}$ uptake rates, whereas surface $\mathrm{NH}_{4}{ }^{+}$uptakes were higher at $\mathrm{M} 4$ and $\mathrm{M} 11$. The total $\mathrm{NO}_{3}{ }^{-}$uptake rates during $2015\left(0.003-0.53\right.$; mean $\left.\pm \mathrm{SD}=0.12 \pm 0.12 \mu \mathrm{mol} \mathrm{Nl}^{-1} \mathrm{~h}^{-1}\right)$ were relatively higher than those during 2012, with relatively high values at stations M10 and M12 (Figure 4). However, total $\mathrm{NH}_{4}{ }^{+}$ uptake rates $\left(0.008-1.17\right.$; mean \pm S.D. $\left.=0.22 \pm 0.24 \mu \mathrm{mol} \mathrm{Nl}^{-1} \mathrm{~h}^{-1}\right)$ did not show considerable variation 
between the 2012 and 2015 ranges except for station M10 (Figures $3 \mathrm{~b}$ and $4 \mathrm{~b}$ ). The small $\mathrm{NO}_{3}{ }^{-}$and $\mathrm{NH}_{4}{ }^{+}$ uptake rates during 2015 ranged between 0.001 and 0.164 (mean \pm S.D. $=0.033 \pm 0.036) \mu \mathrm{mol} \mathrm{Nl} l^{-1} \mathrm{~h}^{-1}$ and 0.010 and 0.304 (mean \pm S.D. $=0.101 \pm 0.073) \mu \mathrm{mol} \mathrm{NL} \mathrm{NL}^{-1}$, respectively.

Figures 5 and 6 show the spatial distribution of total depth-integrated $\mathrm{NO}_{3}{ }^{-}$and $\mathrm{NH}_{4}{ }^{+}$ uptake rates during 2012 and 2015 (total and small). The total depth-integrated uptake rates during $2012\left(\mathrm{NO}_{3}{ }^{-} ; 0.33-2.50, \mathrm{NH}_{4}{ }^{+} ; 1.68-22.4 \mathrm{mmol} \mathrm{N} \mathrm{m}{ }^{-2} \mathrm{~h}^{-1}\right)$ and $2015\left(\mathrm{NO}_{3}^{-} ; 0.15-2.36\right.$, $\mathrm{NH}_{4}^{+}$; 0.39-4.57 mmol N m${ }^{-2} \mathrm{~h}^{-1}$; Table 2) samplings are given in Table 2. The mean \pm S.D. of the depth-integrated total $\mathrm{NO}_{3}{ }^{-}$and $\mathrm{NH}_{4}{ }^{+}$uptake rates were calculated to be $1.19 \pm 0.699$ and $8.45 \pm 6.38 \mathrm{mmol} \mathrm{N} \mathrm{m}^{-2} \mathrm{~h}^{-1}$ during 2012 and $0.783 \pm 0.675$ and $1.47 \pm 1.30 \mathrm{mmol} \mathrm{N} \mathrm{m}^{-2} \mathrm{~h}^{-1}$, respectively, during 2015.
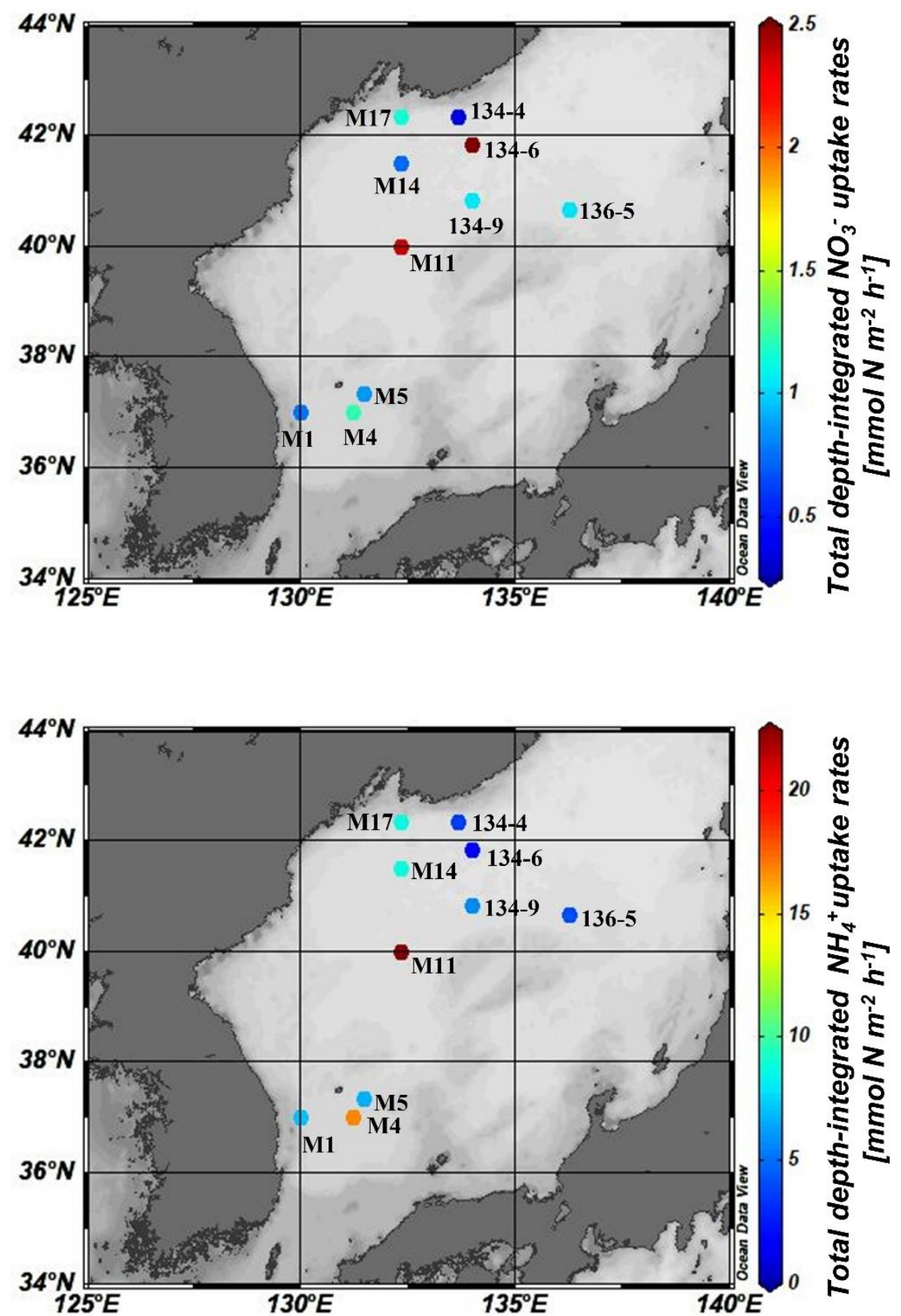

Figure 5. Depth integrated total $\mathrm{NO}_{3}{ }^{-}$and $\mathrm{NH}_{4}{ }^{+}$uptake rates in the East/Japan Sea during 2012. 

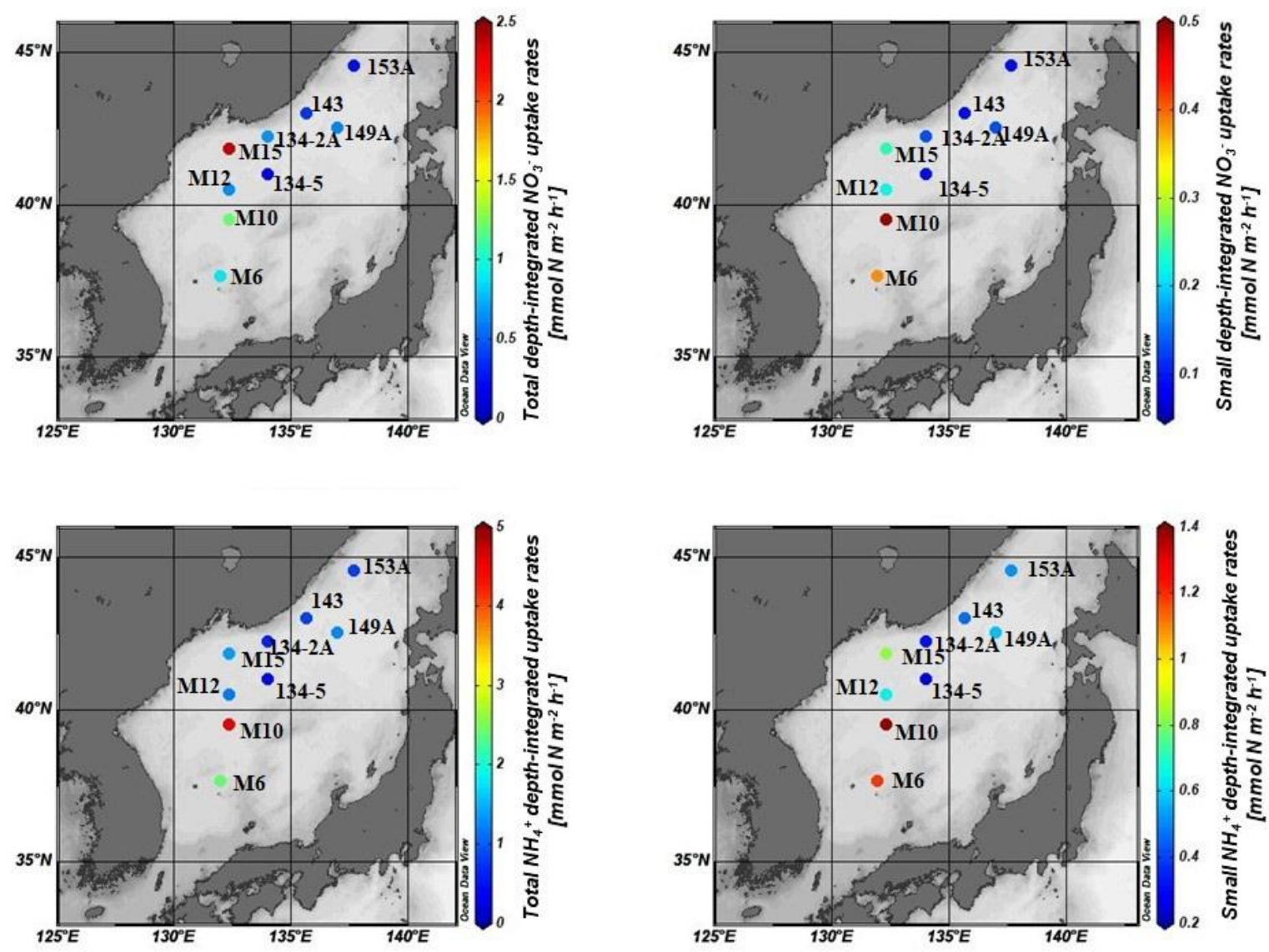

Figure 6. The depth-integrated total and small phytoplankton $\mathrm{NO}_{3}{ }^{-}$and $\mathrm{NH}_{4}{ }^{+}$uptake rates in the East/Japan Sea during 2015. 
Table 2. The depth-integrated total and small phytoplankton uptake rates were obtained during the present study, where uptake rates were given in mmol $\mathrm{N}^{-2} \mathrm{~h}^{-1}$.

\begin{tabular}{|c|c|c|c|c|c|c|c|c|c|c|}
\hline Year & $\begin{array}{l}\text { Stn. } \\
\text { Name }\end{array}$ & Latitude $\left({ }^{\circ} \mathrm{E}\right)$ & Longitude $\left({ }^{\circ} \mathrm{N}\right)$ & $\begin{array}{l}\text { Euphotic } \\
\text { Depth }\end{array}$ & $\begin{array}{c}\text { Total } \mathrm{NO}_{3}{ }^{-} \\
\text {Uptake Rate }\end{array}$ & $\begin{array}{l}\text { Small } \mathrm{NO}_{3}{ }^{-} \\
\text {Uptake Rate }\end{array}$ & $\begin{array}{c}\text { Contribution } \\
(\%)\end{array}$ & $\begin{array}{l}\text { Total } \mathrm{NH}_{4}{ }^{+} \\
\text {Uptake Rate }\end{array}$ & $\begin{array}{l}\text { Small } \mathrm{NH}_{4}{ }^{+} \\
\text {Uptake Rate }\end{array}$ & $\begin{array}{c}\text { Contribution } \\
(\%)\end{array}$ \\
\hline \multirow{10}{*}{2012} & M1 & 37.002 & 129.999 & 27 & 0.750 & - & - & 6.978 & - & - \\
\hline & M4 & 36.990 & 131.232 & 60 & 1.214 & - & - & 16.66 & - & - \\
\hline & M5 & 37.349 & 131.459 & 41 & 0.850 & - & - & 6.587 & - & - \\
\hline & M11 & 40.001 & 132.333 & 54 & 2.365 & - & - & 22.38 & - & - \\
\hline & M14 & 41.501 & 132.337 & 43 & 0.726 & - & - & 8.645 & - & - \\
\hline & M17 & 42.340 & 132.335 & 43 & 1.142 & - & - & 8.578 & - & - \\
\hline & $134-4$ & 42.335 & 133.667 & 46 & 0.333 & - & - & 3.457 & - & - \\
\hline & $134-6$ & 41.831 & 134.003 & 35 & 2.498 & - & - & 1.676 & - & - \\
\hline & $134-9$ & 40.838 & 133.997 & 35 & 1.036 & - & - & 5.586 & - & - \\
\hline & $136-5$ & 40.653 & 136.264 & 54 & 1.023 & - & - & 3.957 & - & - \\
\hline \multirow{9}{*}{2015} & M6 & 37.661 & 131.944 & 35 & 0.873 & 0.377 & 43.18 & 2.381 & 1.184 & 49.72 \\
\hline & M10 & 39.524 & 132.339 & 35 & 1.197 & 0.495 & 41.32 & 4.570 & 1.381 & 30.21 \\
\hline & M12 & 40.513 & 132.331 & 33 & 0.633 & 0.220 & 34.71 & 1.146 & 0.641 & 55.93 \\
\hline & M15 & 41.832 & 132.334 & 41 & 2.363 & 0.242 & 10.24 & 1.351 & 0.823 & 60.94 \\
\hline & $134-2 \mathrm{~A}$ & 42.255 & 134.011 & 43 & 0.653 & 0.127 & 19.39 & 0.586 & 0.323 & 55.20 \\
\hline & $134-5$ & 40.990 & 134.005 & 43 & 0.145 & 0.086 & 59.36 & 0.385 & 0.264 & 68.55 \\
\hline & 143 & 43.000 & 135.657 & 35 & 0.362 & 0.089 & 24.61 & 0.803 & 0.456 & 56.82 \\
\hline & $149 \mathrm{~A}$ & 42.518 & 136.989 & 35 & 0.599 & 0.131 & 21.86 & 1.232 & 0.570 & 46.25 \\
\hline & $153 \mathrm{~A}$ & 44.567 & 137.673 & 30 & 0.227 & 0.087 & 38.49 & 0.792 & 0.508 & 64.13 \\
\hline
\end{tabular}




\subsection{Factors Influencing DIN Uptake Rates in the East/Japan Sea}

Various factors potentially regulate DIN assimilation in marine environments, such as temperature, nutrient availability, and chlorophyll concentrations. The East/Japan Sea is a highly dynamic water body influenced by various water masses and is pivotal for eddies and upwellings [2]. Hence, it is essential to identify the various factors governing the DIN assimilation process in this ecologically crucial marine body. Our study results suggest that the depth-integrated total $\mathrm{NO}_{3}{ }^{-}$uptake rates during 2012 were relatively higher than those during 2015, except for station M15. Similarly, depth-integrated $\mathrm{NH}_{4}{ }^{+}$uptake rates during 2015 showed relatively lower values than those during 2012 (Figure 6). One possible explanation for this could be the higher water column temperature during the autumn in the 2012 sampling period than during the spring in 2015 sampling periods due to the differences in the seasons (Table 1). However, most of the $\mathrm{NO}_{3}{ }^{-}$uptake rates obtained from the individual light depth analysis during 2012 were relatively lower than those during 2015. Additionally, the individual $\mathrm{NO}_{3}{ }^{-}$and $\mathrm{NH}_{4}{ }^{+}$uptake rates from each light depth did not significantly correlate with temperature based on the $t$-test (Figure not shown). Thus, the possibility of temperature as a critical control for DIN uptake rates in the East/Japan Sea during the present study period cannot be projected.

Apart from temperature, nutrient availability is also a critical factor that can control primary production and DIN uptake rates. Since various current systems and localized upwellings govern the East/Japan Sea, a deep understanding of nutrient dynamics is a must to identify the factors controlling DIN assimilation rates. Park et al. [3] reported that the frontal zone between the warm Tsushima current and the nutrient-rich cold polar current often serves as a hub for enhanced primary production. Consequently, this zone can reflect the DIN assimilation rates; hence, our present study also reported high depth-integrated $\mathrm{NO}_{3}{ }^{-}$and $\mathrm{NH}_{4}{ }^{+}$uptake rates (2012: Stations; M15 and M10 and 2015: Stations; M11 and 134-6; Figures 5 and 6).

Despite having lower nutrient concentrations (Figure 2), the surface waters showed higher $\mathrm{NO}_{3}{ }^{-}$ and $\mathrm{NH}_{4}{ }^{+}$uptake rates than deep waters. The $\mathrm{NO}_{3}{ }^{-}$uptake rates had higher surface values than those in the deeper waters except for stations 134-6 (Figure 3a). The insignificant linear correlations between the nutrient concentrations and their respective substrate uptake rates (figure not shown) suggest that the higher depth-integrated $\mathrm{NO}_{3}{ }^{-}$and $\mathrm{NH}_{4}{ }^{+}$uptake rates during the 2012 sampling than during the 2015 sampling cannot be explained by nutrient influence. It suggests that the DIN assimilation rates in the East/Japan Sea during our sampling periods were primarily dependent on light conditions rather than nutrient availability. Our parallel study also reported similar results, where they reported that high primary production rates were mainly found at the surface layers [24].

Another possible reason for the higher depth-integrated $\mathrm{NO}_{3}{ }^{-}$and $\mathrm{NH}_{4}{ }^{+}$values in the previous study than the current study could be the depth of the euphotic zone selected for sampling. The euphotic depths observed were different at almost all stations, ranging from 27 to $60 \mathrm{~m}$ and 30 to $43 \mathrm{~m}$ during 2012 and 2015, respectively. There was no significant correlation observed between euphotic depths and depth-integrated $\mathrm{NO}_{3}{ }^{-}$and $\mathrm{NH}_{4}{ }^{+}$uptake rates during our present study based on the $t$-test. For example, stations M11 $\left(2.37 \mathrm{mmol} \mathrm{N} \mathrm{m}^{-2} \mathrm{~h}^{-1}\right)$ and $134-6\left(2.50 \mathrm{mmol} \mathrm{N} \mathrm{m}^{-2} \mathrm{~h}^{-1}\right)$ during 2012 were observed with higher depth-integrated $\mathrm{NO}_{3}{ }^{-}$uptake rates; their euphotic depths were 54 and $35 \mathrm{~m}$, respectively. However, the station with the deeper euphotic depth (M4;60 m) than the rest was observed with a significantly lower $\mathrm{NO}_{3}{ }^{-}$uptake rate. Similarly, the station (134-2A) with the deeper euphotic depth than the rest during the 2015 sampling also showed a lower depth-integrated $\mathrm{NO}_{3}{ }^{-}$uptake rate $\left(0.65 \mathrm{mmol} \mathrm{N} \mathrm{m}^{-2} \mathrm{~h}^{-1}\right)$ (Table 2). Overall, depth-integrated $\mathrm{NH}_{4}{ }^{+}$uptake rates also did not show any significant relationship with euphotic depth. Hence, the variation in the euphotic depths is not a critical factor in determining the $\mathrm{NO}_{3}{ }^{-}$and $\mathrm{NH}_{4}{ }^{+}$uptake pattern in the present study area.

\subsection{Turnover Times of Nutrients}

The turnover time for any nutrient substrate is a significant tool to understand how fast a substrate is consumed during its assimilation when there is no external inflow or outflow of that substrate. 
Technically, the turnover time estimation is performed by dividing the substrate concentrations with the corresponding uptake rates. Figures 7 and 8 show the $\mathrm{NO}_{3}{ }^{-}$and $\mathrm{NH}_{4}{ }^{+}$turnover times during the 2012 and 2015 sampling periods. The turnover times for $\mathrm{NO}_{3}{ }^{-}$and $\mathrm{NH}_{4}{ }^{+}$substrates during the 2012 sampling, when the total phytoplankton communities are the consumers, show that the consumption of available nutrients in the euphotic zone is very fast till $12 \%$ light levels. However, the turnover times for $\mathrm{NO}_{3}{ }^{-}$were distinctively longer (400-3000 h) than $\mathrm{NH}_{4}{ }^{+}$at depths close to euphotic depth. The low nutrient availability under sufficient light conditions can be the possible reason for the fast nutrient consumption at the surface waters compared to deeper waters with high nutrient concentrations and low light availability. The poor light availability can potentially suppress $\mathrm{NO}_{3}{ }^{-}$uptake, whereas $\mathrm{NH}_{4}{ }^{+}$uptake can still be performed, which leads to faster turnover for $\mathrm{NH}_{4}{ }^{+}$ at the deep waters than that of $\mathrm{NO}_{3}{ }^{-}$.
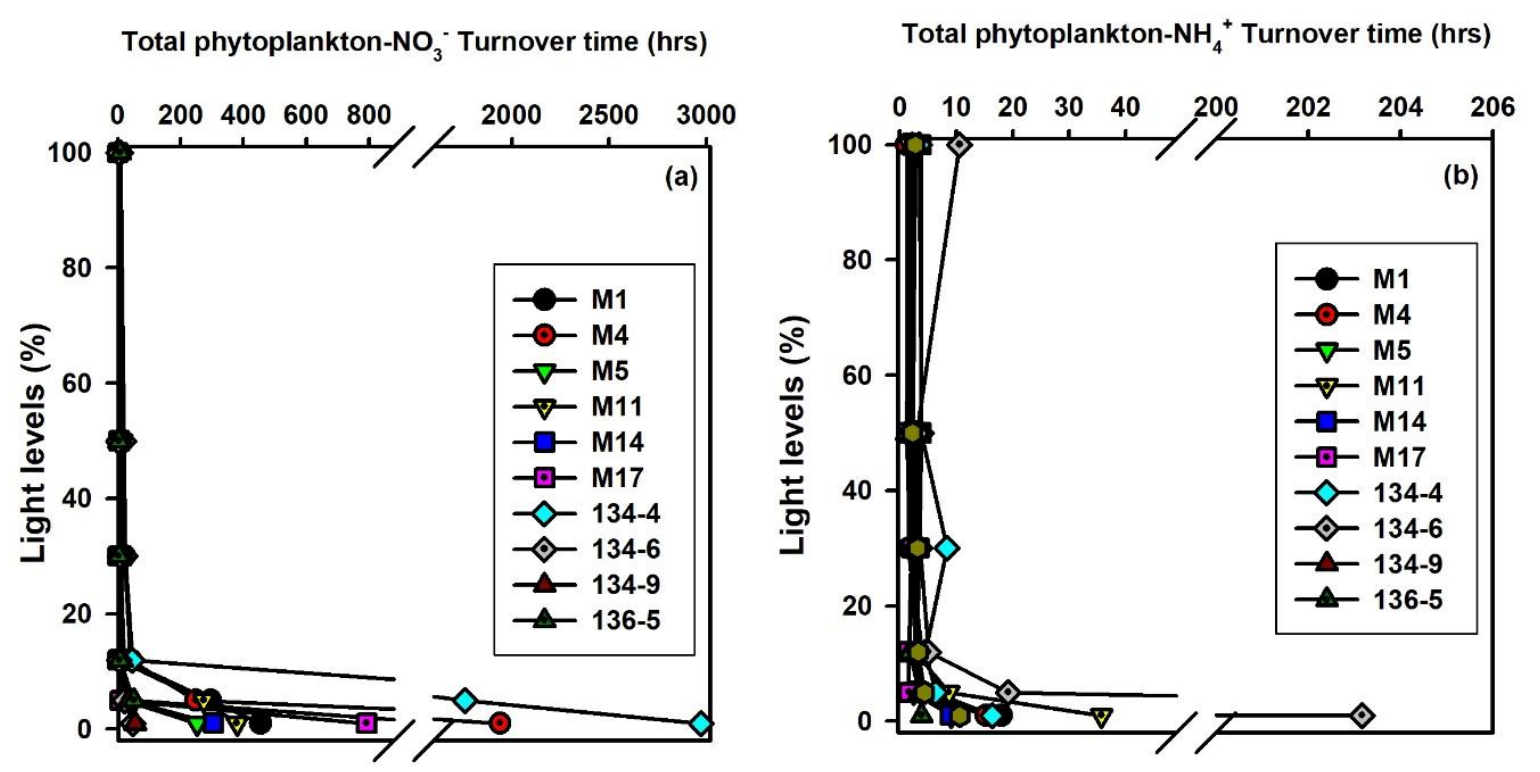

Figure 7. Depth profiles of (a) $\mathrm{NO}_{3}{ }^{-}$and (b) $\mathrm{NH}_{4}{ }^{+}$turnover time by total phytoplankton in the East/Japan Sea during 2012.

Similarly, 2015 sampling also appeared with a faster $\mathrm{NH}_{4}{ }^{+}$turnover time faster than that of $\mathrm{NO}_{3}{ }^{-}$ both at the water column and bottom of the euphotic zone. The differences in turnover times can be due to the relative preference for $\mathrm{NH}_{4}{ }^{+}$over $\mathrm{NO}_{3}{ }^{-}$by the phytoplankton. However, the higher supply of the $\mathrm{NO}_{3}{ }^{-}$substrate in the deep waters than the $\mathrm{NH}_{4}{ }^{+}$substrate can also be one reason for longer turnover times for $\mathrm{NO}_{3}{ }^{-}$at the deep waters. The results from a set of experiments in a tropical eutrophic estuary in India showed rapid turnover times (3-232 $\mathrm{h}$ for $\mathrm{NH}_{4}{ }^{+}$and $7-2419 \mathrm{~h}$ for $\mathrm{NO}_{3}{ }^{-}$) by the total phytoplankton communities for the DIN substrates despite high nutrient concentrations [34]. On the other note, the turnover times in the Arctic Ocean were found to be long despite the low nutrient concentrations [34]. It is also reported that the inhibition of phytoplankton communities for $\mathrm{NO}_{3}{ }^{-}$ uptake under sufficient $\mathrm{NH}_{4}{ }^{+}$concentrations is a widely known phenomenon as they prefer the lighter $\mathrm{NH}_{4}{ }^{+}$over the heavier $\mathrm{NO}_{3}{ }^{-}$substrate [34-36]. Figure 8b, d show the $\mathrm{NO}_{3}{ }^{-}$and $\mathrm{NH}_{4}{ }^{+}$turnover times during 2015 for small phytoplankton communities. Except for the stations 134-2A and 134-5, the small and total phytoplankton turnover times were observed to have a similar range. These two stations showed significantly long turnover times throughout the euphotic zone. The higher $\mathrm{NO}_{3}{ }^{-}$ concentrations and lower $\mathrm{NO}_{3}{ }^{-}$uptake rates by the small phytoplankton communities in the stations 134-2A and 134-5 compared to other stations might be the possible reason. However, such a difference was not observed in the case of $\mathrm{NH}_{4}{ }^{+}$turnover times. 

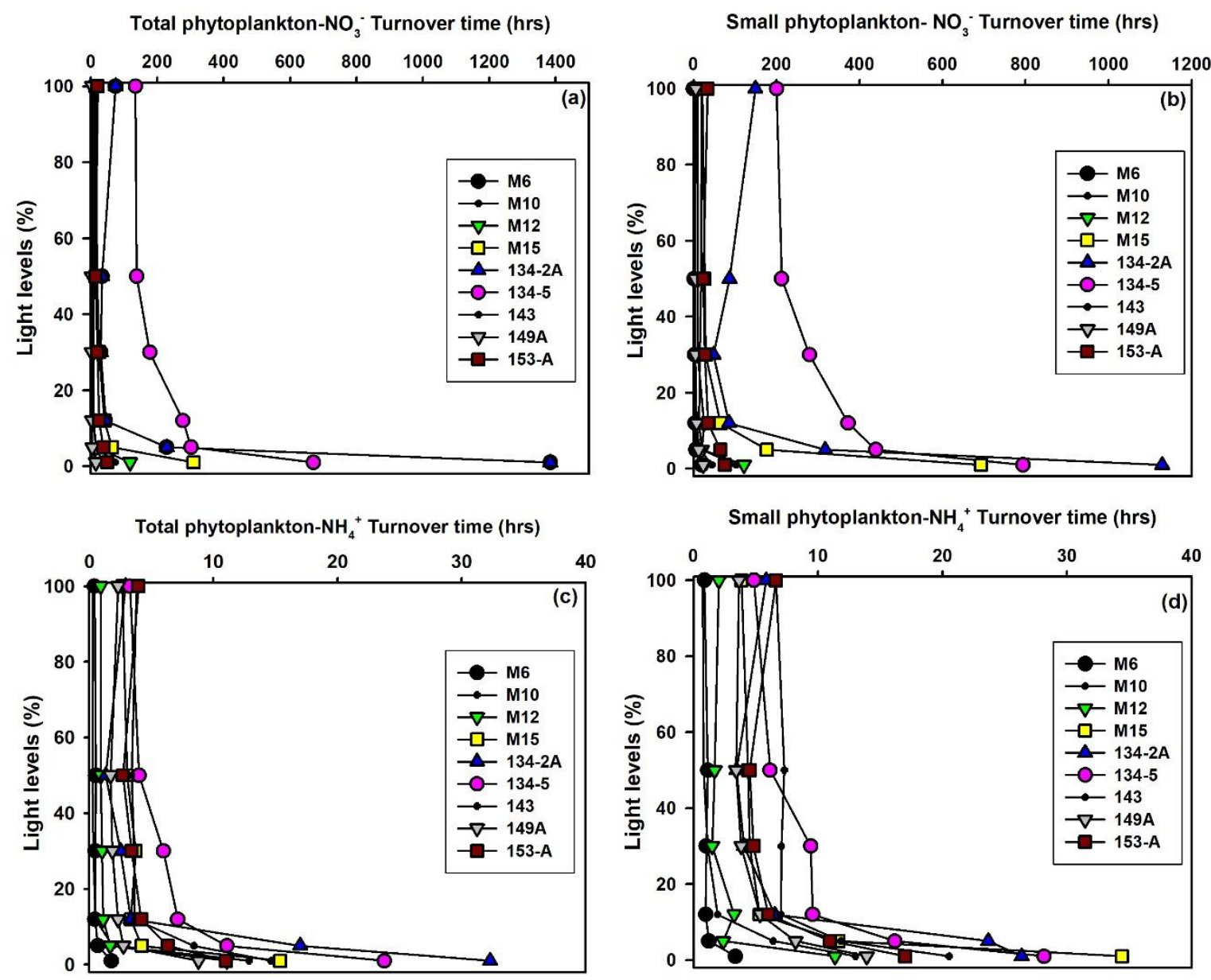

Figure 8. Depth profiles of turnover times of $\mathrm{NO}_{3}{ }^{-}$and $\mathrm{NH}_{4}{ }^{+}$substrates by total and small phytoplankton in the East/Japan Sea during 2015. (a,b) denote the $\mathrm{NO}_{3}{ }^{-}$turnover times by total and small phytoplankton, respectively, and $(\mathbf{c}, \mathbf{d})$ denote the $\mathrm{NH}_{4}{ }^{+}$turnover times by total and small phytoplankton, respectively.

\subsection{Contribution of Small Phytoplankton to Total Nitrogen Uptake}

Experimental and theoretical investigations on small phytoplankton communities have reported that the small phytoplankton possesses higher nutrient uptake rates per unit of biomass and lower half-saturation constants than large phytoplankton due to their higher surface area to volume ratios [37-39]. Therefore, the lower minimum cellular metabolic requirement assists small phytoplankton to survive in nutrient-poor environments [40,41]. Several investigations were conducted globally on this topic, and they reported that the small phytoplankton contribution to the total annual carbon and DIN assimilations generally varied between 20 and 65\% [22-24,42,43]. The MODIS-derived data in the Ulleung Basin in the East/Japan Sea from 2003 to 2012 showed that the annual contribution of small phytoplankton communities varies between $19.6 \%$ and $28.4 \%$, with an average of $23.6 \%$ $(\mathrm{SD}= \pm 8.1 \%)$ [23], which suggests that the large phytoplankton communities are the major contributors to primary production in the Ulleung Basin.

Basin-wide studies suggest that small phytoplankton contributions mainly control primary production in the Japan Basin and Yamato Basin at $85 \%$ and $82 \%$, respectively. In contrast, the Ulleung Basin has a smaller phytoplankton contribution (35\%) [34]. Lee et al. [24] (our parallel study) also reported a similar range of small phytoplankton contributions to the total primary production in the Ulleung Basin during 2015. Lee et al. [24] also reported that the contributions of small phytoplankton $(<2 \mu \mathrm{m})$ to the total carbon uptake rates have significant spatial and temporal variations. They found remarkable differences in small phytoplankton contributions during 2012 (60.6\%) and 2015 
(34.1\%) samplings. Unfortunately, the data for small phytoplankton uptake is unreliable due to lack of enough material for the stable isotope measurements; the contributions to the total $\mathrm{NO}_{3}{ }^{-}$and $\mathrm{NH}_{4}{ }^{+}$ uptake rates during 2015 were only taken for the present discussion (Table 2).

The contributions of small phytoplankton to the total $\mathrm{NO}_{3}{ }^{-}$and $\mathrm{NH}_{4}{ }^{+}$uptake rates during 2015 were 32.6 and $54.2 \%$, respectively, which indicate that small phytoplankton is not the dominant contributor to the total $\mathrm{NO}_{3}{ }^{-}$assimilation in the East/Japan Sea. The sampling period during 2015 was before the spring bloom, which is reported to be dominated by large cell diatoms [9,24]. Interestingly, small phytoplankton cells significantly contributed to the $\mathrm{NH}_{4}{ }^{+}$uptake rates in comparison to large phytoplankton cells. Previous studies have reported a clear preference for $\mathrm{NO}_{3}{ }^{-}$by large phytoplankton cells $[29,44-47]$, where small cells depend primarily on regenerated nitrogen, such as $\mathrm{NH}_{4}{ }^{+}$, e.g., [36,45-47]. However, large cell phytoplankton is highly dependent on the threshold availability of the $\mathrm{NO}_{3}{ }^{-}$substrate $[48,49]$, where large cell dominance was observed when $\mathrm{NO}_{3}{ }^{-}$ concentrations were above $3.5 \mu \mathrm{M}$. A similar dependency of large cell phytoplankton on $\mathrm{NO}_{3}{ }^{-}$ availability was reported by Tamigneaux et al. [50] in nearshore Baie des Chaleurs, Canada. Interestingly, Wilkerson et al. [51] observed much higher threshold $\mathrm{NO}_{3}{ }^{-}$concentrations $(10-12 \mu \mathrm{M})$ than those above, where the percent contributions by the large cells to PON and Chl-a were always more than $50 \%$ [52]. In contrast, the present study showed that the station with the highest $\mathrm{NO}_{3}{ }^{-}$concentrations (134-5; close to $10 \mu \mathrm{M}$ ) and lowest $\mathrm{NH}_{4}{ }^{+}$concentrations showed high contributions (59\% and $69 \%$ ) of small phytoplankton to the total $\mathrm{NO}_{3}{ }^{-}$and $\mathrm{NH}_{4}{ }^{+}$uptake rates, respectively.

Notably, the high $\mathrm{NO}_{3}{ }^{-}$concentrations in oligotrophic waters primarily depend on upwelling that brings $\mathrm{NO}_{3}{ }^{-}$rich bottom waters to the surface. A few studies were conducted to investigate the alteration in phytoplankton species composition in response to upwelled cold water in the southwestern East/Japan Sea [52]. Kim et al. [52] also reported that the phytoplankton abundance and the proportion of large phytoplankton were higher when there was upwelling-induced nutrient-rich cold water than when there was strong vertical stratification. In general, these studies point toward the influence of nutrient-rich upwelled bottom water on the abundance and composition of phytoplankton communities in the East/Japan Sea. However, a few investigations are available on the C and DIN uptake rates by small and large phytoplankton and their response to vertical mixing due to upwelling in the East/Japan Sea [24]. The present study did not estimate the contribution of bacteria to the total DIN uptake rates; therefore, the role of bacteria in DIN assimilation and dissolved organic nitrogen as a nitrogen source could not be assessed.

\subsection{Impact of Small Phytoplankton on the Total DIN Assimilation Rates}

Observational and model studies on the impact of increasing small phytoplankton uptake suggest that primary productivity will decrease if small phytoplankton becomes the predominant species $[24,53-56]$. Since our study did not include species identification and abundance, the discussion on species diversity is limited in this regard. However, a few studies recorded the species identification and abundance from the East/Japan Sea, although the study regions are slightly different from the present study $[34,56]$. The reported studies suggest that the overall dominant groups could be diatoms with some large spatial variations in our study area during spring, summer, and fall seasons [57]. Prymenesiophytes were the second dominant group during spring and fall seasons, and cyanobacterial abundance was very low over seasons [57].

Several studies reported that, when large phytoplankton communities dominate, the primary productivity obtained will be higher than when small phytoplankton dominate [58-61]. Similarly, Lee et al. [24] found a significant negative relationship between total primary productivity and the small phytoplankton contribution in the East/Japan Sea. However, few studies have evaluated the influence of small phytoplankton contributions on total DIN uptake rates. Previously, Wilkerson et al. [51] also suggested that, in comparison to the dominance of small cells $(<5 \mu \mathrm{m})$, the dominance of large phytoplankton cells $>5 \mu \mathrm{m}$ can potentially lead to higher $\mathrm{C}$ and DIN assimilation rates. The present study also observed a significant negative relationship $\left(\mathrm{R}^{2}=0.77, t\right.$-test; $\left.p<0.01\right)$ of total $\mathrm{NH}_{4}{ }^{+}$ 
uptake rates with the increasing small phytoplankton contribution. The total $\mathrm{NO}_{3}{ }^{-}$uptake rates also showed a negative correlation of $\mathrm{R}^{2}=0.30$ with a $p$-value $<0.05$ ( $t$-test) with the contribution of small phytoplankton (Figure 9). The possible reason for the relatively high significance level in the correlation between the small phytoplankton contribution and the total $\mathrm{NH}_{4}{ }^{+}$than that with $\mathrm{NO}_{3}{ }^{-}$uptake rates during the present study could have been due to the dominance of $\mathrm{NH}_{4}{ }^{+}$uptake since $\mathrm{NH}_{4}{ }^{+}$is the most preferred substrate [30].

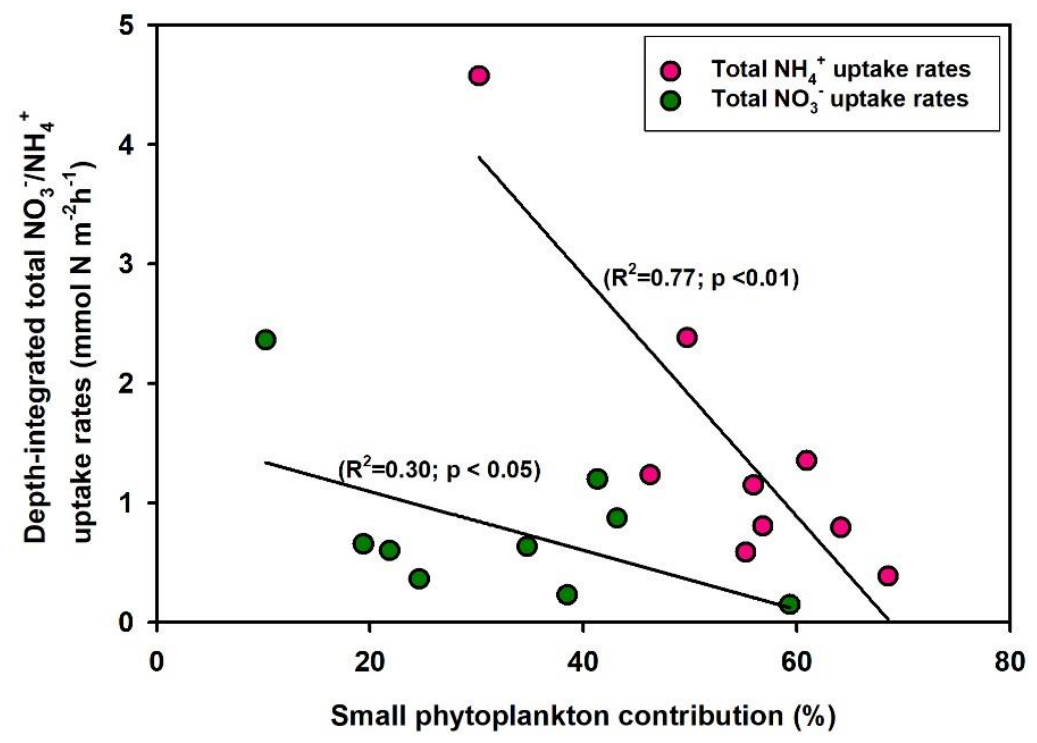

Figure 9. Relationships between small phytoplankton contributions to $\mathrm{NO}_{3}{ }^{-} / \mathrm{NH}_{4}{ }^{+}$uptake rates and total $\mathrm{NO}_{3}{ }^{-} / \mathrm{NH}_{4}{ }^{+}$uptake rates in the northeastern East/Japan Sea during 2015. The green and magenta dots indicate depth-integrated total $\mathrm{NO}_{3}{ }^{-}$and $\mathrm{NH}_{4}{ }^{+}$uptake rates, respectively. The significance levels for the correlations are obtained from the $t$-test.

Although the small phytoplankton communities prefer $\mathrm{NH}_{4}{ }^{+}$as the significant substrate, the high contributions of small phytoplankton to the total $\mathrm{NH}_{4}{ }^{+}$uptake rates did not appear to be a supporting element in sustaining the high total $\mathrm{NH}_{4}{ }^{+}$uptake rates in the East/Japan Sea during the present study. The results suggest that, if the small phytoplankton species are the dominant species in the future due to global warming, then the East/Japan Sea may have decreased $\mathrm{NH}_{4}{ }^{+}$assimilation rate compared to the present time. The possibility of a decrease in $\mathrm{NO}_{3}{ }^{-}$uptake under a small phytoplankton-dominant environment in the East/Japan Sea cannot be neglected. The main consumers of the $\mathrm{NO}_{3}{ }^{-}$substrate are large cell phytoplankton such as diatoms. Specifically, the water column stratification introduced by global warming can lead to small cell phytoplankton dominance. The abundance and uptake of large cell phytoplankton may reduce as the availability of $\mathrm{NO}_{3}{ }^{-}$reduce in the absence of upwelling under thermal stratification $[10,15,62]$. Additionally, small cell phytoplankton preferentially assimilates regenerated nutrient forms such as $\mathrm{NH}_{4}{ }^{+}$, whose availability is not primarily dependent on upwelling. Therefore, total DIN assimilation can be widely impacted by its rates, processes, and fluxes under ongoing warming conditions in the East/Japan Sea.

In general, studies on the abundance, size, and assimilation rates of phytoplankton communities under in situ and simulated conditions suggest that global warming phenomena can potentially reduce DIN assimilation rates $[10,62]$. These studies also suggest that the uptake efficiency of small cell phytoplankton is relatively lower than that of large cell phytoplankton. Hence, there will be a decrease in total primary production and DIN assimilation rates in the global oceans if a condition of small phytoplankton dominance occurs [11]. Since the functioning of the marine food web is entirely dependent on the capability of phytoplankton communities to assimilate carbon and DIN, any alteration that affects their efficiency would significantly redefine the food distribution in the 
entire ecosystem. Therefore, it is highly essential to record factors influencing phytoplankton size, abundance, and assimilation rates in global oceans.

\section{Conclusions}

The present study estimated the DIN uptake rates by total and small phytoplankton $(<2 \mu \mathrm{m})$ in the East/Japan Sea as a part of the Korea-Russia joint expeditions during 2012 and 2015. The study used the dual isotopic tracer technique to estimate the DIN uptake rates. The primary objectives were to understand the spatiotemporal variations in the DIN assimilation rates by total and small phytoplankton and their contribution to the total DIN uptake rates. The study also aimed to understand the various environmental factors that play vital roles in governing nitrogen dynamics in the East/Japan Sea. There were no significant correlations between environmental parameters and the DIN uptake rates observed during the present study; however, the higher DIN uptake rates in the surface layers than in the bottom waters suggest the potential influence of light conditions. The results show that 10.24 to $59.36 \%$ and 30.21 to $68.55 \%$ of the total $\mathrm{NO}_{3}{ }^{-}$and $\mathrm{NH}_{4}{ }^{+}$uptake rates are contributed by small phytoplankton. The results from the present study found that there is a negative correlation between the depth-integrated $\mathrm{NH}_{4}{ }^{+}$uptake rates and the small phytoplankton contribution, which suggests the adverse effect of increasing the small phytoplankton population as a result of global warming on the nitrogen assimilation process. In general, the results from the present study provide significant information on the potential for reduced DIN assimilation conditions in the East/Japan Sea if the small phytoplankton abundance increases as a result of global warming. Since the East/Japan Sea is an economically and ecologically important ecosystem, it is highly relevant to have a set of monitoring experiments on its potential to assimilate carbon and nitrogen under varying environmental conditions.

Author Contributions: Conceptualization, P.S.B. and S.H.L.; data curation, P.S.B., J.H.L. (Jae Hyung Lee) and K.K.; formal analysis, P.S.B., J.J.K., H.K.J., H.J., J.H.L. (Jae Hyung Lee), J.H.L. (Jang Han Lee), J.W.P. and K.K.; investigation, H.K.J., H.J., J.H.L. (Jae Hyung Lee), J.H.L. (Jang Han Lee), J.W.P. and K.K.; methodology, H.K.J., H.J., J.H.L. (Jae Hyung Lee), J.H.L. (Jang Han Lee), J.W.P., K.K. and S.H.L.; validation, J.H.L. (Jae Hyung Lee), H.C.K.; visualization, P.S.B.; writing-original draft, P.S.B. and S.H.L.; writing-preview \& editing, P.S.B., H.C.K. and S.H.L. All authors have read and agreed to the published version of the manuscript.

Funding: This research was funded by the Ministry of Oceans and Fisheries, Korea (project: Long-term change in structure and function in marine ecosystems of Korea; 20140507) and the National Institute of Fisheries Science (NIFS; R2020048).

Acknowledgments: The authors thank the cruise crew members and other scientific staff for their support during sampling and lab work. The authors also would like to thank the anonymous reviewers. We also thank the Ministry of Oceans and Fisheries, Korea (project: Long-term change in structure and function in marine ecosystems of Korea; 20140507) and the National Institute of Fisheries Science (NIFS; R2020048) for the financial support for the present study.

Conflicts of Interest: The authors declare no conflict of interest.

\section{References}

1. Kawai, H. Transition of current images in the Japan Sea. In Tsushima Warm Current-Ocean Structures and Fishery; The Japanese Society of Fisheries Science: Tokyo, Japan, 1974; pp. 7-26.

2. Sorokin, Y.I. The heterotrophic phase of plankton succession in the Japan Sea. Mar. Biol. 1977, 41, 107-117. [CrossRef]

3. Park, K.-A.; Ullman, D.S.; Kim, K.; Chung, J.Y.; Kim, K.-R. Spatial and temporal variability of satellite-observed Subpolar Front in the East/Japan Sea. Deep. Sea Res. Part I Oceanogr. Res. Pap. 2007, 54, 453-470. [CrossRef]

4. Kang, Y.S.; Kim, J.Y.; Kim, H.G.; Park, J.H. Long term changes in zooplankton and its relationship with squid, Todarodes pacificus, catch in the East/Japan Sea. Fish. Oceanogr. 2002, 11, 337-346. [CrossRef]

5. Kim, D.; Yang, E.J.; Kim, K.H.; Shin, C.-W.; Park, J.; Yoo, S.; Hyun, J.-H. Impact of an anticyclonic eddy on the summer nutrient and chlorophyll a distribution in the Ulleung Basin, East Sea (Japan Sea). ICES J. Mar. Sci. 2011, 69, 23-29. [CrossRef] 
6. Lim, J.-H.; Son, S.; Park, J.-W.; Kwak, J.H.; Kang, C.-K.; Son, Y.B.; Kwon, J.-N.; Lee, S.H. Enhanced biological activity by an anticyclonic warm eddy during early spring in the East Sea (Japan Sea) detected by the geostationary ocean color satellite. Ocean Sci. J. 2012, 47, 377-385. [CrossRef]

7. Hyun, J.-H.; Kim, D.; Shin, C.-W.; Noh, J.-H.; Yang, E.-J.; Mok, J.-S.; Kim, S.-H.; Kim, H.-C.; Yoo, S. Enhanced phytoplankton and bacterioplankton production coupled to coastal upwelling and an anticyclonic eddy in the Ulleung basin, East Sea. Aquat. Microb. Ecol. 2008, 54, 45-54. [CrossRef]

8. Yoo, S.; Park, J. Why is the southwest the most productive region of the East Sea/Sea of Japan? J. Mar. Syst. 2009, 78, 301-315. [CrossRef]

9. Kwak, J.H.; Lee, S.H.; Park, H.J.; Choy, E.J.; Jeong, H.D.; Kim, K.R.; Kang, C.-K. Monthly measured primary and new productivities in the Ulleung Basin as a biological "hot spot" in the East/Japan Sea. Biogeosciences 2013, 10, 4405-4417. [CrossRef]

10. Joo, H.; Park, J.W.; Son, S.; Noh, J.-H.; Jeong, J.-Y.; Kwak, J.H.; Saux-Picart, S.; Choi, J.H.; Kang, C.-K.; Lee, S.H. Long-term annual primary production in the Ulleung Basin as a biological hot spot in the East/Japan Sea. J. Geophys. Res. Ocean. 2014, 119, 3002-3011. [CrossRef]

11. Thomas, M.K.; Kremer, C.T.; Klausmeier, C.A.; Litchman, E. A Global Pattern of Thermal Adaptation in Marine Phytoplankton. Science 2012, 338, 1085-1088. [CrossRef]

12. Bhavya, P.S.; Lee, J.H.; Lee, H.W.; Kang, J.J.; Lee, J.H.; Lee, D.; An, S.H.; Stockwell, D.A.; Whitledge, T.E.; Lee, S.H. First in situ estimations of small phytoplankton carbon and nitrogen uptake rates in the Kara, Laptev, and East Siberian seas. Biogeosciences 2018, 15, 5503-5517. [CrossRef]

13. Chiba, S.; Saino, T. Variation in mesozooplankton community structure in the East/Japan Sea (1991-1999) with possible influence of the ENSO scale climatic variability. Prog. Oceanogr. 2003, 57, 317-339. [CrossRef]

14. Zhang, C.I.; Lee, J.B.; Young, I.S.; Yoon, S.C.; Kim, S. Variations in the abundance of fisheries resources and ecosystem structure in the East/Japan Sea. Prog. Oceanogr. 2004, 61, 245-265. [CrossRef]

15. Chiba, S.; Batten, S.; Sasaoka, K.; Sasai, Y.; Sugisaki, H. Influence of the Pacific Decadal Oscillation on phytoplankton phenology and community structure in the western North Pacific. Geophys. Res. Lett. 2012, 39, L15603. [CrossRef]

16. Li, W.K.W.; McLaughlin, F.A.; Lovejoy, C.; Carmack, E.C. The smallest algae thrive as the Arctic Ocean freshens. Science 2009, 326, 539. [CrossRef]

17. Yun, M.S.; Whitledge, T.E.; Stockwell, D.; Son, S.H.; Lee, J.H.; Park, J.W.; Lee, D.B.; Park, J.; Lee, S.H. Primary production in the Chukchi Sea with potential effects of freshwater content. Biogeosciences 2016, 13, 737-749. [CrossRef]

18. Kim, K.-R.; Kim, K.; Kang, D.-J.; Park, S.Y.; Park, M.-K.; Kim, Y.-G.; Min, H.S.; Min, D. The East Sea (Japan Sea) in Change: A Story of Dissolved Oxygen. Mar. Technol. Soc. J. 1999, 33, 15-22. [CrossRef]

19. Kim, K.; Kim, K.-R.; Min, D.-H.; Volkov, Y.; Yoon, J.-H.; Takematsu, M. Warming and structural changes in the East (Japan) Sea: A clue to future changes in global oceans? Geophys. Res. Lett. 2001, 28, 3293-3296. [CrossRef]

20. Kang, D.J.; Park, S.; Kim, Y.G.; Kim, K.; Kim, K.-R. A moving-boundary box model (MBBM) for oceans in change: An application to the East/Japan Sea. Geophys. Res. Lett. 2003, 30, 1299. [CrossRef]

21. Chiba, S.; Aita, M.N.; Tadokoro, K.; Saino, T.; Sugisaki, H.; Nakata, K. From climate regime shifts to lower-trophic level phenology: Synthesis of recent progress in retrospective studies of the western North Pacific. Prog. Oceanogr. 2008, 77, 112-126. [CrossRef]

22. Lee, S.H.; Son, S.; Dahms, H.-U.; Park, J.W.; Lim, J.-H.; Noh, J.-H.; Kwon, J.-I.; Joo, H.T.; Jeong, J.Y.; Kang, C.-K. Decadal changes of phytoplankton chlorophyll-a in the East Sea/Sea of Japan. Oceanology 2014, 54, 771-779. [CrossRef]

23. Joo, H.T.; Sun, S.; Park, J.W.; Kang, J.J.; Jeong, J.-Y.; Lee, C.I.; Kang, C.K.; Lee, S.H. Long-term pattern of primary productivity in the East/Japan Sea based on ocean color data derived from MODIS-aqua. Remote Sens. 2016, 8, 25. [CrossRef]

24. Lee, S.H.; Joo, H.; Lee, J.H.; Lee, J.H.; Kang, J.J.; Lee, H.W.; Lee, D.; Kang, C.-K. Seasonal carbon uptake rates of phytoplankton in the northern East/Japan Sea. Deep Sea Res. Part II Top. Stud. Oceanogr. 2017, 143, 45-53. [CrossRef]

25. French, R.H.; Cooper, J.J.; Vigg, S. Secchi Disc Relationships. J. Am. Water Resour. Assoc. 1982, 18, 121-123. [CrossRef]

26. Lee, S.H.; Whitledge, T.E. Primary and new production in the deep Canada Basin during summer. Polar Biol. 2002, 28, 190-197. [CrossRef] 
27. Lee, S.H.; Whitledge, T.E.; Kang, S.H. Recent carbon and nitrogen uptake rates of phytoplankton in Bering Strait and the Chukchi Sea. Cont. Shelf Res. 2007, 27, 2231-2249. [CrossRef]

28. Parsons, T.R.; Maita, Y.; Lalli, C.M. A Manual of Chemical and Biological Methods for Seawater Analysis; Pergamon Press: New York, NY, USA, 1984.

29. Garneau, M.E.; Gosselin, M.; Klein, B.; Tremblay, J.E.; Fouilland, E. New and regenerated production during a late summer bloom in an Arctic polynya. Mar. Ecol. Prog. Ser. 2007, 345, 13-26. [CrossRef]

30. Dugdale, R.C.; Goering, J.J. Uptake of new and regenerated forms of nitrogen in primary productivity. Limnol. Oceanogr. 1967, 12, 196-206. [CrossRef]

31. Hama, T.; Miyazaki, T.; Ogawa, Y.; Iwakuma, T.; Takahashi, M.; Otsuki, A.; Ichimura, S. Measurement of phytosynthetic production of a marine phytoplankton population using a stable 13C isotope. Mar. Biol. 1983, 73, 31-36. [CrossRef]

32. Gandhi, N.; Ramesh, R.; Laskar, A.; Sheshshayee, M.; Shetye, S.S.; Anilkumar, N.; Patil, S.M.; Mohan, R. Zonal variability in primary production and nitrogen uptake rates in the southwestern Indian Ocean and the Southern Ocean. Deep Sea Res. Part I Oceanogr. Res. Pap. 2012, 67, 32-43. [CrossRef]

33. Dugdale, R.C.; Wilkerson, F.P. The use of $15 \mathrm{~N}$ to measure nitrogen uptake in eutrophic oceans; experimental considerations. Limnol. Oceanogr. 1986, 31, 673-689. [CrossRef]

34. Kwak, J.H.; Lee, S.H.; Hwan, J.; Suh, Y.S.; Park, H.J.; Chang, K.I.; Kim, K.R.; Kang, C.K. Summer primary productivity and phytoplankton community composition driven by different hydrographic structures in the East/ Japan Sea and the Western Subarctic Pacific. J. Geophy. Res. Ocean. 2014, 119, 4505-4519. [CrossRef]

35. Bhavya, P.S.; Kumar, S.; Gupta, G.V.M.; Sudheesh, V.; Sudharma, K.V.; Varrier, D.S.; Dhanya, K.R.; Saravanane, N. Nitrogen Uptake Dynamics in a Tropical Eutrophic Estuary (Cochin, India) and Adjacent Coastal Waters. Chesap. Sci. 2015, 39, 54-67. [CrossRef]

36. Glibert, P.M.; Biggs, D.C.; McCarthy, J.J. Utilization of ammonium and nitrate during austral summer in the Scotia Sea. Deep Sea Res. Part A Oceanogr. Res. Pap. 1982, 29, 837-850. [CrossRef]

37. Eppley, R.W.; Thomas, W.H. Comparison of half-saturation constants for growth and nitrate uptake of marine phytoplankton. J. Phycol. 1969, 5, 375-379. [CrossRef]

38. Aksnes, D.L.; Egge, J.K. A theoretical model for nutrient uptake in phytoplankton. Mar. Ecol. Prog. Ser. 1991, 70, 65-72. [CrossRef]

39. Hein, M.; Folager Pedersen, M.; Sand-Jensen, K. Size-dependent nitrogen uptake in micro and macroalgae. Mar. Ecol. Prog. Ser. 1995, 118, 247-253. [CrossRef]

40. Shuter, B.G. Size dependence of phophorus and nitrogen subsistence quotas in unicellular microrganisms. Limnol. Oceanogr. 1978, 23, 1248-1255. [CrossRef]

41. Grover, J.P. Resource competition in a variable environment: Phytoplankton growing according to the variable-internal-stores model. Am. Nat. 1991, 138, 811-835. [CrossRef]

42. Agawin, N.S.R.; Duarte, C.M.; Agustí, S. Nutrient and temperature control of the contribution of picoplankton to phytoplankton biomass and production. Limnol. Oceanogr. 2000, 45, 591-600. [CrossRef]

43. Hodal, H.; Kristiansen, S. The importance of small-celled phytoplankton in spring blooms at the marginal ice zone in the northern Barents Sea. Deep Sea Res. Part II Top. Stud. Oceanogr. 2008, 55, 2176-2185. [CrossRef]

44. Malone, T.C. Size-Fractionated Primary Productivity of Marine Phytoplankton. In Primary Productivity in the Sea; Springer: Boston, MA, USA, 1980; pp. 301-319.

45. Nalewajko, C.; Garside, C. Methodological problems in the simultaneous assessment of photosynthesis and nutrient uptake in phytoplankton as functions of light intensity and cell size. Limnol. Oceanogr. 1983, 28, 591-597. [CrossRef]

46. Probyn, T.A. Nitrogen uptake by size-fractionated phytoplankton populations in the southern Benguela upwelling system. Mar. Ecol. Prog. Ser. Oldendorf. 1985, 22, 249-258. [CrossRef]

47. Koike, I.; Holm-Hansen, O.; Biggs, D.C. Inorganic nitrogen metabolism by Antarctic phytoplankton with special reference to ammonium cycling. Mar. Ecol. Prog. Ser. 1986, 30, 105-116. [CrossRef]

48. Dauchez, S.; Legendre, L.; Fortier, L.; Levasseur, M. Nitrate uptake by size-fractionated phytoplankton on the Scotian Shelf (Northwest Atlantic): Spatial and temporal variability. J. Plank. Res. 1996, 18, 577-595. [CrossRef]

49. Dauchez, S.; Legendre, L.; Fortier, L.; Levasseur, M. New production and production of large phytoplankton (>5 um) on the Scotian Shelf (NW Atlantic). Mar. Ecol. Prog. Ser. 1996, 135, 215-222. [CrossRef] 
50. Tamigneaux, E.; Vazquez, E.; Mingelbier, M.; Klein, B.; Legendre, L. Environmental control of phytoplankton assemblages in nearshore marine waters, with special emphasis on phototrophic ultraplankton. J. Plankton Res. 1995, 17, 1421-1448. [CrossRef]

51. Wilkerson, F.; Dugdale, R.; Kudela, R.; Chavez, F.P. Biomass and productivity in Monterey Bay, California: Contribution of the large phytoplankton. Deep Sea Res. Part II Top. Stud. Oceanogr. 2000, 47, 1003-1022. [CrossRef]

52. Kim, B.K.; Joo, H.; Song, H.J.; Yang, E.J.; Lee, S.H.; Hahm, D.; Rhee, T.S.; Lee, S.H. Large seasonal variation in phytoplankton production in the Amundsen Sea. Polar Biol. 2015, 38, 319-331. [CrossRef]

53. Lee, S.H.; Yun, M.S.; Kim, B.K.; Joo, H.T.; Kang, S.H.; Kang, C.-K.; Whitledge, T.E. Contribution of small phytoplankton to total primary production in the Chukchi Sea. Cont. Shelf Res. 2013, 68, 43-50. [CrossRef]

54. Siegel, D.A.; Buesseler, K.O.; Doney, S.C.; Sailley, S.F.; Behrenfeld, M.J.; Boyd, P.W. Global assessment of ocean carbon export by combining satellite observations and food-web models. Glob. Biogeochem. Cycles 2014, 28, 181-196. [CrossRef]

55. Lim, Y.J.; Kim, T.-W.; Lee, S.H.; Lee, D.; Park, J.; Kim, B.K.; Kim, K.; Jang, H.K.; Bhavya, P.; Lee, S.H. Seasonal Variations in the Small Phytoplankton Contribution to the Total Primary Production in the Amundsen Sea, Antarctica. J. Geophys. Res. Ocean. 2019, 124, 8324-8341. [CrossRef]

56. Kwak, J.H.; Han, E.; Lee, S.H.; Park, H.J.; Kim, K.R.; Kang, C.K. A consistent structure of phytoplankton communities across the warm-cold regions of the water mass on a meridional transect in the East/Japan Sea. Deep Sea Res. Part II Top. Stud. Oceanogr. 2017, 143, 36-44. [CrossRef]

57. Goldman, J.C. Potential role of large oceanic diatoms in new primary production. Deep Sea Res. Part I Oceanogr. Res. Pap. 1993, 40, 159-168. [CrossRef]

58. Michaels, A.F.; Silver, M.W. Primary production, sinking fluxes, and the microbial food web. Deep Sea Res. Part A Oceanogr. Res. Pap. 1988, 35, 473-490. [CrossRef]

59. Uitz, J.; Claustre, H.; Gentili, B.; Stramski, D. Phytoplankton class-specific primary production in the world's oceans: Seasonal and interannual variability from satellite observations. Glob. Biogeochem. Cycles 2010, 24. [CrossRef]

60. Winder, M.; Sommer, U. Phytoplankton response to a changing climate. Hydrobiologia 2012, 698, 5-16. [CrossRef]

61. Moran, X.A.G.; Lopez-Urrutia, A.; Calvo-Diaz, A.; Li, W.K.W. Increasing importance of small phytoplankton in a warmer ocean. Glob. Chang. Biol. 2010,16, 1137-1144. [CrossRef]

62. Gregg, W.W.; Conkright, M.E.; Ginoux, P.; O’Reilly, J.E.; Casey, N.W. Ocean primary production and climate: Global decadal changes. Geophys. Res. Lett. 2003, 15, 1809. [CrossRef]

Publisher's Note: MDPI stays neutral with regard to jurisdictional claims in published maps and institutional affiliations.

(C) 2020 by the authors. Licensee MDPI, Basel, Switzerland. This article is an open access article distributed under the terms and conditions of the Creative Commons Attribution (CC BY) license (http://creativecommons.org/licenses/by/4.0/). 